\title{
Carboniferous deposits of northern Sierra de Tecka, central-western Patagonia, Argentina: paleontology, biostratigraphy and correlations
}

\author{
Arturo C. Taboada ${ }^{1}$, M. Alejandra Pagani ${ }^{2}$, M. Karina Pinilla ${ }^{3}$, \\ M. Franco Tortello ${ }^{3}$, César A. Taboada ${ }^{2}$
}

\author{
${ }^{I}$ Centro de Investigación Esquel de Montaña y Estepa Patagónicas (CIEMEP), CONICET-UNPSJB, Roca 780, Esquel (9200), Chubut, \\ Argentina; Laboratorio de Investigaciones en Evolución y Biodiversidad (LIEB), Facultad de Ciencias Naturales y de la Salud Sede \\ Esquel, UNPSJB, RN 259, km 16,5, Esquel, Chubut, Argentina. \\ taboadaart@gmail.com; ataboada@unpata.edu.ar \\ ${ }^{2}$ Museo Paleontológico Egidio Feruglio (MEF), Avda. Fontana 140, Trelew (9100), Chubut, Argentina. \\ apagani@mef.org.ar; tukunaturales@gmail.com \\ ${ }^{3}$ División Paleozoología de Invertebrados, Museo de Ciencias Naturales de La Plata, Paseo del Bosque s/n, La Plata (1900), Buenos \\ Aires, Argentina. \\ mkapinilla@fcnym.unlp.edu.ar; tortello@fcnym.unlp.edu.ar
}

\begin{abstract}
A narrow upper Paleozoic belt crops out in the northern tip of Sierra de Tecka through the Quebrada de Güera-Peña (Patagonia, Argentina). There, black shales of the Pampa de Tepuel Formation contain marine fossil invertebrates previously listed as belonging to the "Levipustula" fauna. Material recently recorded by the authors comprises, in order of abundance, gastropods [Glabrocingulum (Glabrocingulum) poperimense (Maxwell), G. (Stenozone) argentinum (Reed), G. (Stenozone) sp., Peruvispira teckaensis sp. nov., Ananias riccardii Pinilla], bivalves [Nuculopsis (Nuculopsis) patagoniensis González, Phestia tepuelensis González, Streblochondria sueroi González, Streblopteria sp.], conulariids [Paraconularia cf. ugartei Cúneo and Sabattini], brachiopods [Amosia sueroi Simanauskas, Languigneotus laevicaudatum (Amos), Beecheria patagonica Amos], trilobites [Australosutura argentinensis Hahn and Hahn], cephalopods [Pseudoorthoceratidae Flower and Caster, Sueroceras? sp., Mitorthoceras? sp.], and rugose corals [?Lophophyllidiidae Moore and Jeffords]. In addition, the present study includes the new key brachiopods Languigneotus dammanorum gen. et sp. nov. and Tuberculatella waterhousei sp. nov. from younger localities of the Tepuel-Genoa Basin. The Languigneotus laevicaudatum and Languigneotus-Verchojania subzones (late Pennsylvanian) are proposed herein to replace the former Tuberculatella Zone. In addition, previous stratigraphic relationships and correlations of the study section with the Arroyo Pescado (Estancia Ap Iwan) and Esquel areas are discussed. The general stratigraphic profile of a glacial-related section cropping out at Estancia Ap Iwan includes lower conglomeradic beds, which are reinterpreted as early Jurassic in age, and glacimarine levels that are partially equivalent to the Pampa de Tepuel Formation but older than those of Quebrada de Güera-Peña. A correlation of the Esquel Formation with the Arroyo Pescado Formation and other contemporaneous units on the paleopacific margin is assessed, implying that the Esquel Formation should be segregated from the Tepuel Group. The Esquel and Arroyo Pescado formations can be regarded as the basement of the glaciomarine column of the Tepuel-Genoa Basin.
\end{abstract}

Keywords: Brachiopoda, Bivalvia, Gastropoda, Trilobita, Cnidaria, Carboniferous, Patagonia, Argentina.

RESUMEN. Los depósitos carboníferos del norte de la Sierra de Tecka, centro-oeste de Patagonia, Argentina: paleontología, bioestratigrafía y correlaciones. Una estrecha faja neopaleozoica aflora atravesando el extremo norte de la Sierra de Tecka a lo largo de la Quebrada de Güera-Peña (Patagonia, Argentina). Alli, lutitas negras de la Formación Pampa de Tepuel contienen invertebrados marinos previamente asignados a la fauna de "Levipustula". Nuevo material coleccionado por los autores incluye, en orden de abundancia, gastrópodos [Glabrocingulum (Glabrocingulum) poperimense (Maxwell), G. (Stenozone) argentinum (Reed), G. (Stenozone) sp., Peruvispira teckaensis sp. nov., Ananias riccardii Pinilla], bivalvos [Nuculopsis (Nuculopsis) patagoniensis González, Phestia tepuelensis González, Streblochondria sueroi González, Streblopteria sp.], conuláridos [Paraconularia cf. ugartei Cúneo y Sabattini], braquiópodos [Amosia 
sueroi Simanauskas, Languigneotus laevicaudatum (Amos), Beecheria patagonica Amos], trilobites [Australosutura argentinensis Hahn y Hahn], cefalópodos [Pseudoorthoceratidae Flower y Caster, Sueroceras? sp., Mitorthoceras? sp.] y corales rugosos [?Lophophyllidiidae Moore y Jeffords]. El presente estudio incluye además los nuevos braquiópodos clave Languigneotus dammanorum gen. et sp. nov. y Tuberculatella waterhousei sp. nov. provenientes de otras localidades más jóvenes de la cuenca. Se proponen formalmente las subzonas de Languigneotus laevicaudatum y de LanguigneotusVerchojania, en reemplazo de la anteriormente equivalente Zona de Tuberculatella. Se discuten las relaciones estratigráficas y correlaciones previamente propuestas para la sección estudiada en relación a las áreas de Arroyo Pescado (Estancia Ap Iwan) y Esquel. El perfil estratigráfico general de la sección con influencia glacial aflorante en la Estancia Ap Iwan incluye una parte inferior con conglomerados que son reasignados al Jurásico inferior, y tramos superiores que son parcialmente equivalentes a la Formación Pampa de Tepuel pero más antiguos que los aflorantes en la Quebrada de Güera Peña. Por otro lado, se refuerza la correlación de la Formación Arroyo Pescado con la Formación Esquel, así como con otras unidades contemporáneas reconocidas hacia el oeste, sobre el margen paleopacífico. La correlación de las formaciones Esquel y Arroyo Pescado implica segregar la primera del Grupo Tepuel, así como considerar a las mismas como basamento de la columna estratigráfica de la Cuenca de Tepuel-Genoa.

Palabras clave: Brachiopoda, Bivalvia, Gastropoda, Trilobita, Cnidaria, Carbonifero, Patagonia, Argentina.

\section{Introduction}

A narrow ENE-WNW-trending upper Paleozoic belt crops out in the northern tip of Sierra de Tecka (central-west Patagonia, Argentina). This belt has a maximum width of nearly two kilometers, and extends for about eight kilometers by the High Tension Line that stretches from the Futaleufú Hydroelectric Station in the Patagonian Andes to Puerto Madryn City on the Atlantic coast (Fig. 1). Outcrops include black shales with marine fossil invertebrates that were previously referred to the "Levipustula fauna" (Sabattini in Alberti, 1988; Vizán et al., 1996). Although this material was not originally described in detail, it enabled Vizán et al. (1996) (see also Alberti, 1988; Revol, 1988) to assign these rocks to the Pampa de Tepuel Formation (Lesta and Ferello, 1972; emend. Page et al., 1984).

Field-work carried out by different working groups at different times (C.R. González, A.C. Taboada and M.A. Aredes in 1992; J. Hlebszevitsch and M.A. Pagani in 1999; A.C. Taboada, M.A. Pagani and
M.K. Pinilla in 2015) allowed to recover hundreds of samples from the Quebrada de Güera-Peña locality (Fig. 2). Fossils include, in order of abundance, gastropods, bivalves, conulariids, brachiopods, trilobites, cephalopods and corals. The aim of this work is to carry out a systematic study of this material and some related taxa in order to refine the knowledge of the paleontology and biostratigraphy of the northern Sierra de Tecka. On the basis of the studied fauna, the current biostratigraphic scheme of the upper Paleozoic of central-west Patagonia is updated. Also, correlations of this Carboniferous belt with other well-known sections of the Tepuel-Genoa Basin are discussed, testing in particular stratigraphic ties previously made at other northern outcrops such as those of the Esquel and Arroyo Pescado areas.

\section{Geological and stratigraphic setting}

The Upper Paleozoic deposits of central-west Patagonia infilled the Tepuel-Genoa Basin, which extends between $43^{\circ}-44^{\circ} 20^{\prime} \mathrm{S}$ and $69^{\circ} 30^{\prime}-71^{\circ} \mathrm{W}$

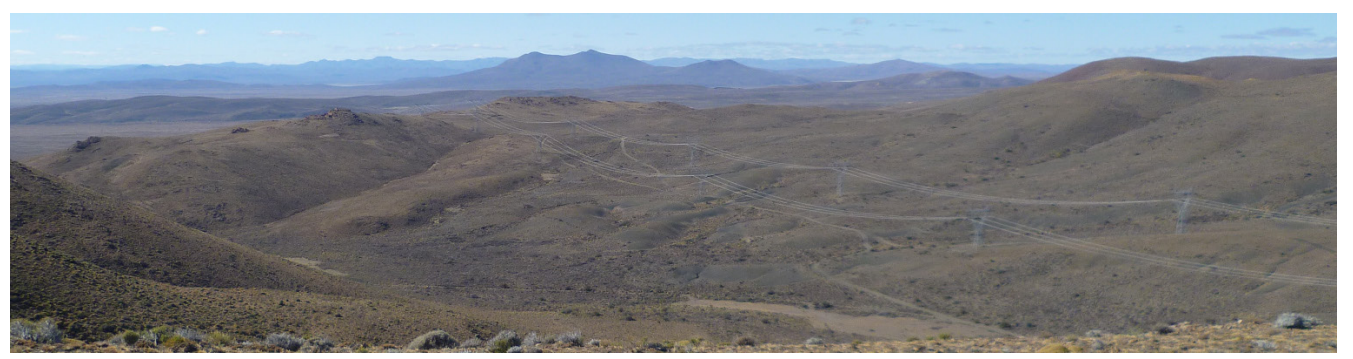

FIG. 1. General southeastward view of the Quebrada de Güera-Peña. 


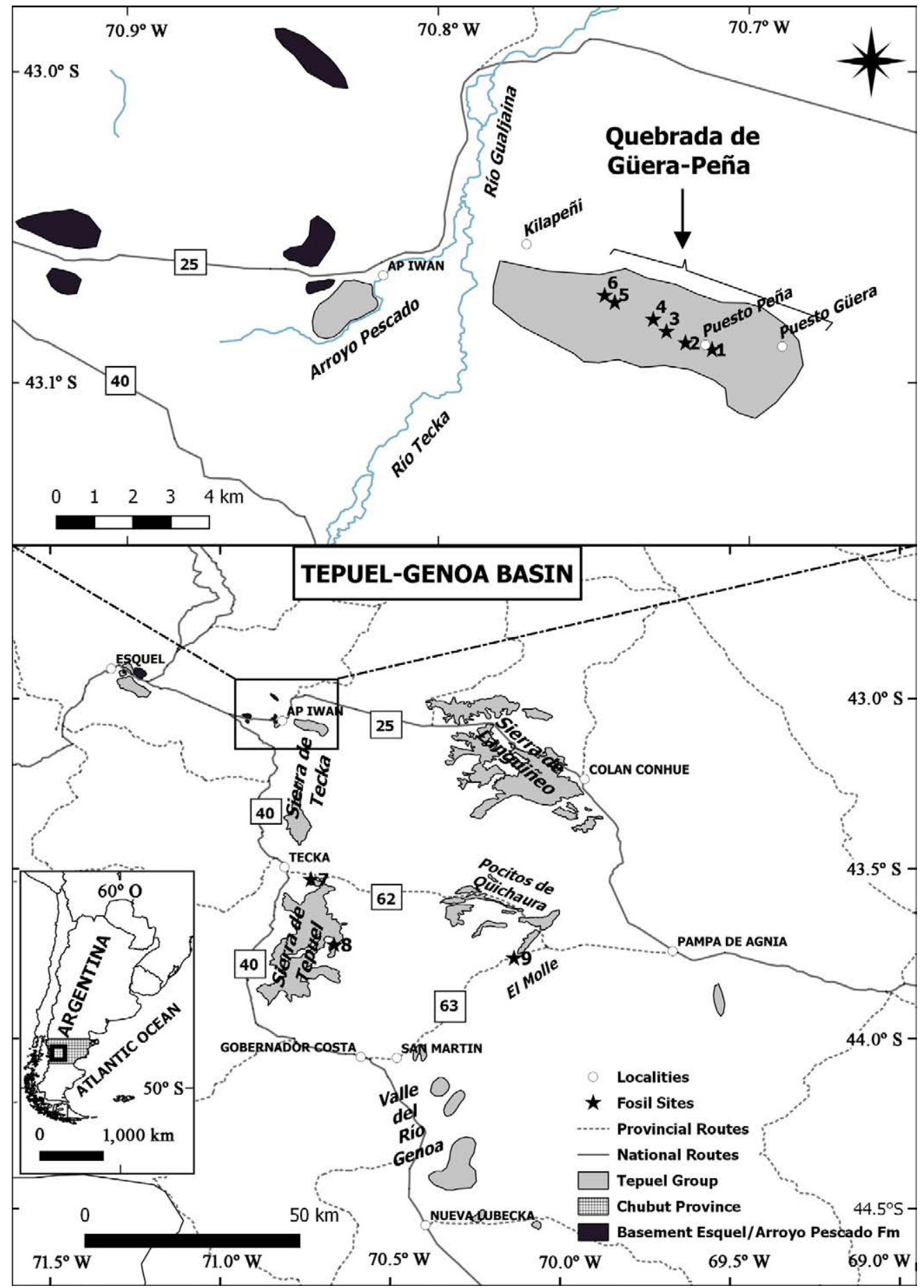

FIG. 2. Location map showing main Carboniferous outcrops of the Tepuel-Genoa Basin, its basement (Esquel and Arroyo Pescado formations) and fossiliferous localities 1-9. Fossil sites 1-6, located upstream at right bank of Quebrada de Güera-Peña, northern Sierra de Tecka, upper half of Pampa de Tepuel Formation; Fossil-site 7, $900 \mathrm{~m}$ ENE of Puesto La Carlota, upper half of Pampa de Tepuel Formation; Fossil-site 8, 4 km to the east of Puesto Tres Lagunas, Sierra de Tepuel, upper part of Mojón de Hierro Formation; Fossil-site 9, $1 \mathrm{~km}$ to the east of Puesto Lefiú, El Molle area, upper part of Pampa de Tepuel Formation. 
for approximately $250 \mathrm{~km}$ in central-western Chubut Province. Patagonia was located at the southwestern margin of Gondwana and was possibly separated from southern South America as an independent block that collided with the continental margin during late Paleozoic times (Ramos, 1984, 2008; Pankhurst et al., 2006). Upper Paleozoic rocks of the basin are widely exposed in the north-south arranged Sierras de Tepuel, Tecka, Languiñeo, Cerro Excursión and Valle Chico (near the town of Esquel), Valle del Río Genoa, El Molle and Pampa de Agnia regions (Fig. 2). After the pioneer studies of Keidel (1922) and Piatnitzky (1933, 1936), Suero (1948, 1953, 1958) first outlined the general stratigraphy of the basin and determined the Late Paleozoic age of these deposits, based mainly on preliminary identifications of plants and marine invertebrates remains. Many subsequent studies allowed a better understanding of the stratigraphy, paleoenvironment and paleontological content of the basin (Pagani and Taboada, 2010 and references therein). The most commonly used stratigraphic nomenclature was proposed by Page et al. (1984), who identified a tripartite succession that includes the Jaramillo, Pampa de Tepuel and Mojón de Hierro formations (Freytes in Lesta and Ferello, 1972; emend. Page et al., 1984). The Río Genoa Formation (Lesta and Ferello, 1972; emend. Andreis et al., 1986) assembles the southernmost outcrops of the basin, and is interpreted as partially equivalent to the Mojón de Hierro Formation (Lesta and Ferello, 1972; Page et al., 1984; Andreis et al., 1986; Hlebszebitsch and Sabattini, 2005). Recently, Taboada and Pagani (2010) and Pagani and Taboada (2011) suggested a possible minor lateral interfingering between the uppermost part of the Mojón de Hierro Formation and the lowermost part of the Río Genoa Formation. These formations constitute the Tepuel Group, a major lithostratigraphic unit with its type section in the Sierra de Tepuel (Suero, 1948; nom. subs. Borrello, 1969; emend. Page et al., 1984). The Tepuel Group is a late Tournaisian-Artinskian glacial-influenced siliciclastic sequence nearly $6,000 \mathrm{~m}$ thick that unconformably overlies the Catreleo Devonian granite (Robbiano, 1971) and underlies Lower Jurassic marine strata.

Upper Paleozoic strata are also exposed in the northeast corner of the basin, in the Sierra de Languiñeo, where they are assigned to the Las Salinas Formation (González, 1972), and in a region close to Esquel City, where the Esquel (Feruglio, 1941; nom. subs. Cazau, 1972; emend. Cucchi, 1980) and
Valle Chico (Cucchi, 1980) formations crop out. These units were correlated to the lower and middle parts of the Tepuel Group (González, 1972; López Gamundi, 1980; Cucchi, 1980; Andreis et al., 1986; Carrizo and Azcuy, 2006; Taboada and Shi, 2011).

A few kilometers east the northern tip of Sierra de Tecka, near the Arroyo Pescado/Estancia Ap Iwan, there is another area with Upper Paleozoic deposits (González et al., 1995 and references therein) (Fig. 2). The stratigraphy of this region was compiled by Vizán et al. (1996), and is further discussed below.

\subsection{Summary of key biota events throughout the Tepuel Group}

Abundant invertebrate fossil remains have been reported from the Pampa de Tepuel, Mojón de Hierro, and Río Genoa formations, whereas the Jaramillo Formation is poorly fossiliferous (Pagani and Taboada, 2010 and references therein). Several glacial-related intervals with coarse diamictites and black shales with and/or without dropstones, together with intercalated conglomerates and siltstones, characterize the middle and upper thirds of the Pampa de Tepuel Formation. Intercalated black shales (interglacial horizons) bear marine invertebrate fossils of the Lanipustula fauna, whereas faunal assemblages characterized by Verchojania and Languigneotus (a new brachiopod genus herein proposed) appear toward the top of the unit. The overlying Mojón de Hierro Formation exhibits black shales with intercalated pinkish sandstone beds in the lower half of the unit, while yellowish to greenish sandstones and minor intercalated conglomerates, diamictites, shales with and/or without dropstones and siltstones are present upward. The lower half of the formation is characterized by the Cimmeriella fauna, and the upper half bears a Glossopteris flora (below and above a glacial-related horizon) (Taboada et al., 2005, 2009; Taboada, 2008, 2010; Pemberton, 2010; Taboada and Pagani, 2010) and the Kochiproductus-Costatumulus faunal assemblage (Pagani and Taboada, 2011). Further south, the Río Genoa Formation consists of yellowish to greenish sandstones and black shales with some intercalated conglomerates and siltstones bearing the Glossopteris flora and faunal associations characterized by the brachiopods Jakutoproductus Kaschirtzev, Costatumulus Waterhouse, Piatnitzkya Taboada and Magniplicatina Waterhouse (Pagani and Taboada, 2011) (Fig. 3). 
$\mathbf{N}$

\begin{tabular}{l|l|l} 
Esquel & Sierra de Tepuel & Valle del Río Genoa \\
\hline
\end{tabular}

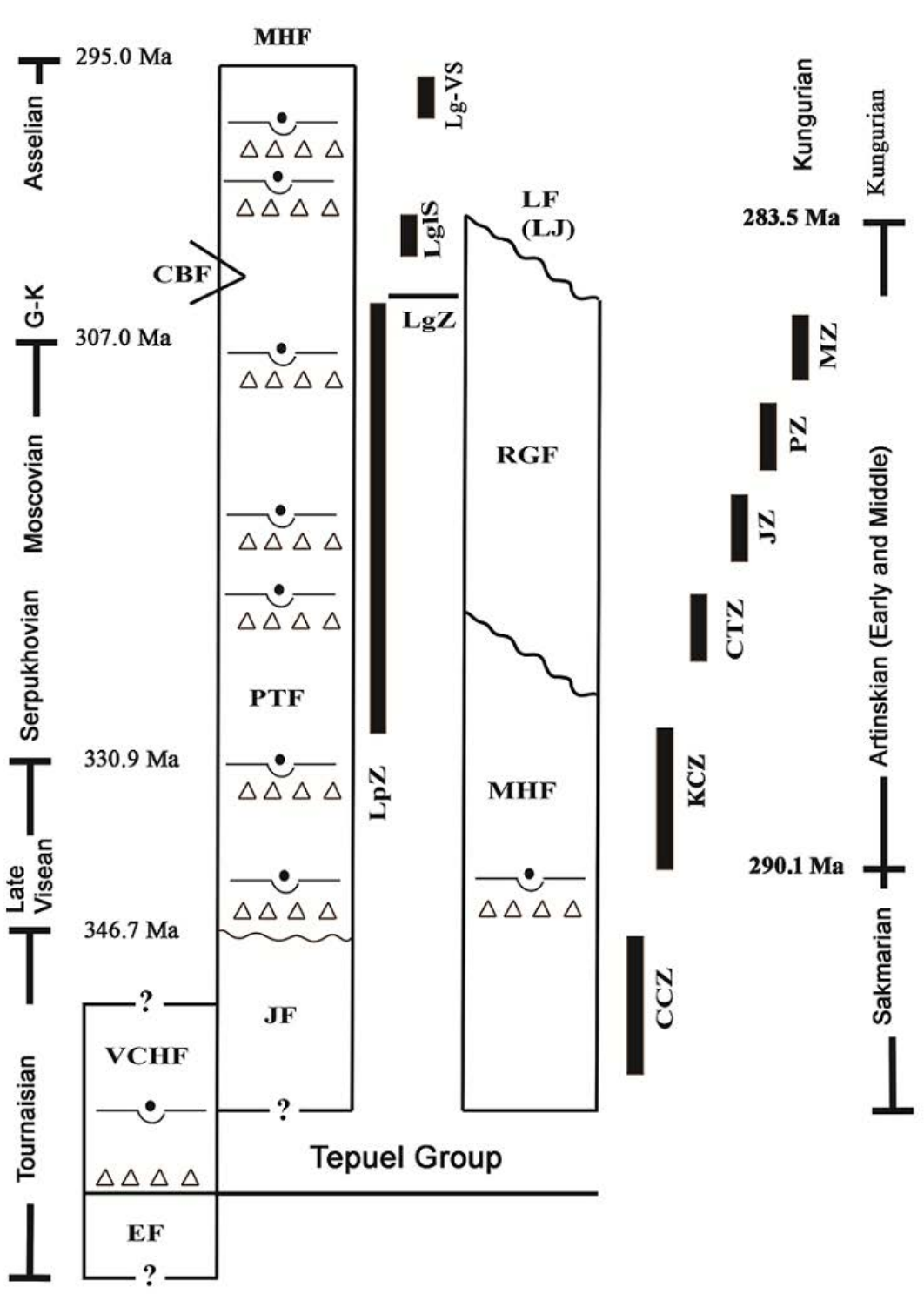

FIG. 3. Time-space scheme showing the stratigraphic column of the Tepuel Group with its main lithostratigraphic units, recognized mayor glacial-related horizons throughout the sequence and stratigraphic position of brachiopod Zones and Subzones characterizing the Tournaisian-Artinskian column in Patagonia (based on Suero, 1948; Taboada, 2008, 2010; Taboada and Pagani, 2010; Pagani and Taboada, 2011; Taboada and Shi, 2011; and updated authors observations). Reference for diamictites and associated facies of glacial-related horizons are white triangles below dropstone symbol. Reference for lithostratigraphic units and brachiopod Zones and Subzones: EF: Esquel Formation; VCHF: Valle Chico Formation; JF: Jaramillo Formation; PTF: Pampa de Tepuel Formation; MHF: Mojón de Hierro Formation; RGF: Río Genoa Formation; CBF: Cresta de Los Bosques Formation; LF: Lepá Formation; LJ: Lower Jurassic; LpZ: Lanipustula patagoniensis Zone; LgZ: Languigneotus Zone; LgIS: Languigneotus laevicaudatum Subzone; Lg-VS: Languigneotus-Verchojania Subzone; CCZ: Cimmeriella-Costatumulus Zone; KCZ: Kochiproductus-Costatumulus Zone; CTZ: Costatumulus-Tivertonia Zone; JZ: Jakutoproductus Zone; PZ: Piatnitzkya Zone; MZ: Magniplicatina Zone; G-K: Gzhelian-Kasimovian. Lithostratigraphic units and Global Stages without scale. Stage-Age boundaries based on Cohen et al. (2013). 


\section{Stratigraphy and paleontological content at northern Sierra de Tecka}

The studied section was mapped near the northwestern corner of the "Geological Chart 44c Tecka" by Turner (1982), although it was not segregated from the Jurassic Lepá Formation until Vizán et al. (1996) regarded it as a fossiliferous Carboniferous succession. An E-W stratigraphic section of unknown base near Puesto Güera is about $700 \mathrm{~m}$ thick and unconformably underlies the Jurassic marine Lepá Formation at both sides of the Quebrada de GüeraPeña. Alternations of sandstones and conglomerates with intercalations of shales characterize the lower half of the section, while black shales with fossiliferous concretions dominate the upper half (Alberti, 1988; Vizán et al., 1996) (Fig. 4A).

Sabattini (in Alberti, 1988) provided a preliminary list of the faunas of northern Sierra de Tecka (see also Vizán et al., 1996), including the brachiopod Beecheria patagonica Amos, 1958, the conulariid Paraconularia sp., the trilobite Australosutura gardneri (Mitchell, 1922), and the gastropods Glabrocingulum argentinum (Reed, 1927) and Mourlonia (Pseudobaylea) poperimensis (Maxwell, 1964). This association was referred to the currently Lanipustula Zone, which at that time was regarded as middle Carboniferous in age (Amos, 1964; Amos and Rolleri, 1965; Riccardi and Sabattini, 1975; González, 1985; Archangelsky et al., 1980).

The material described herein allows us to confirm the presence of Beecheria patagonica Amos, Paraconularia cf. P. ugartei Cúneo and Sabattini, 1987, Australosutura argentinensis Hahn and Hahn, 1969, Glabrocingulum (Glabrocingulum) poperimense (Maxwell, 1964) and Glabrocingulum (Stenozone) argentinum (Reed, 1927). New records include the brachiopods Amosia sueroi Simanauskas, 1996 and Languigneotus laevicaudatum (Amos, 1960); the gastropods Peruvispira teckaensis sp. nov., Ananias riccardii Pinilla, 2012 and Glabrocingulum (Stenozone) sp. 1; the bivalves Nuculopsis (Nuculopsis) patagoniensis González, 1969, Phestia tepuelensis González, Streblochondria sueroi González, 1969, and Streblopteria sp.; the cephalopods Sueroceras? sp., Mitorthoceras? sp. and Pseudoorthoceratidae indet; and the rugose coral-?Lophophyllidiidae indet. In addition, the brachiopods Languigneotus dammanorum gen. et sp. nov. and Tuberculatella waterhousei sp. nov. from younger beds at the top of the Pampa de Tepuel Formation and the upper part of the Mojón de Hierro Formation, respectively, are here proposed in order to discuss and clarify the generic and specific relationships of these key taxa.

\subsection{Biostratigraphy}

The marine invertebrates of the Carboniferous section at northern Sierra de Tecka include species that are restricted to the Tepuel-Genoa Basin, as well as species that have also been described from central-western Argentina (Uspallata-Iglesia Basin) and eastern Australia (Yarrol Basin).

Among the brachiopods, the commonest species is Beecheria patagonica, which was first reported from the upper half of the Pampa de Tepuel Formation at northern Sierra de Tepuel and Sierra de Languiñeo (Amos, 1958). In addition, B. patagonica has recently been described from El Paso Formation in central-western Argentina (Uspallata-Iglesia Basin) (Cisterna and Sterren, 2016; Cisterna et al., 2017) in association with the Serpukhovian RugosochonetesBulahdelia fauna (Taboada, 1989, 2010). On the other hand, Languigneotus laevicaudatum, Amosia sueroi Simanauskas, and the trilobite Australosutura argentinensis have been reported so far in the Tepuel-Genoa Basin at Sierra de Tepuel and Sierra de Languiñeo (Amos, 1960; Simanauskas, 1996; Simanauskas and Sabattini, 1997), suggesting a potencial endemicity of these taxa in the region during the Late Paleozoic. Paraconularia cf. $P$. ugartei closely resembles conulariids that have previously been described from the younger Río Genoa Formation (Cúneo and Sabattini, 1987). Although Peruvispira teckaensis sp. nov. and Glabrocingulum (Stenozone) sp. 1 are known so far only from northern Sierra de Tecka, other gastropods such as Glabrocingulum (Glabrocingulum) poperimense and Glabrocingulum (Stenozone) argentinum exhibit a wider geographic distribution. $G$. (G.) poperimense was originally described by Maxwell (1964) from the Branch Creek and Poperima formations of the Yarrol Basin (Queensland, Australia), in association with Levipustula levis Maxwell, 1951, whereas in Patagonia it occurs in the upper third of the Pampa de Tepuel, Mojón de Hierro and Río Genoa formations (Sabattini and Noirat, 1969; Simanauskas and Sabattini, 1997) of northern Sierra de Tepuel, Sierra de Languiñeo, Pampa de Agnia and Ferrarotti (see Pinilla, 2014). Likewise, Glabrocingulum 


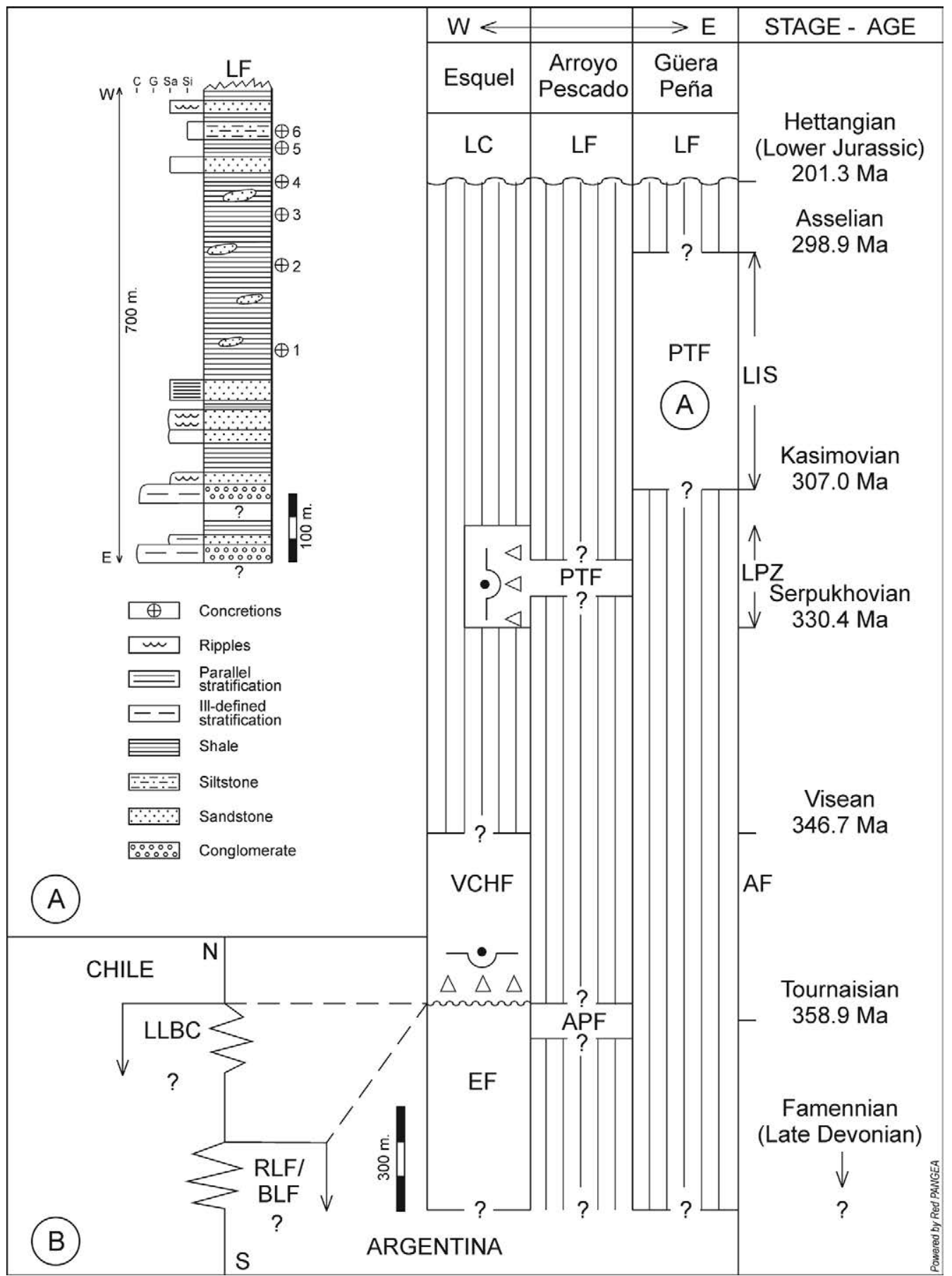

FIG. 4. A. Stratigraphic column at Quebrada de Güera-Peña with location of fossil-sites 1-6. B. Time-space scheme showing stratrigraphic relationship of outcrops at Quebrada de Güera-Peña, Arroyo Pescado (Estancia Ap. Iwan) and Esquel areas, and correlation with coeval units westward to the Argentine-Chilean border. EF: Esquel Formation; APF: Arroyo Pescado Formation; VCHF: Valle Chico Formation; PTF: Pampa de Tepuel Formation; LC: La Cautiva Formation; LF: Lepá Formation; RLF: Río Lácteo Formation; BLF: Bahía de la Lancha Formation; LLBC: Llanquihue basement complex; AF: Archaeosigillaria Flora; LPZ: Lanipustula patagoniensis Zone; LIS: Languigneotus laevicaudatum Subzone. Lithostratigraphic units at Esquel, Arroyo Pescado and Quebrada de Güera-Peña at scale. Global Stages without scale. Stage-Age boundaries based on Cohen et al. (2013). 
(Stenozone) argentinum (Reed) is known from the Pituil and Hoyada Verde formations in the UspallataIglesia Basin (central-western Argentina), associated with the Marginovatia-Maemia and Levipustula levis faunas, respectively (Reed, 1927; Sabattini, 1980; Taboada, 1997, 2010). In Patagonia, G. (S.) argentinum (Reed) was reported from the Pampa de Tepuel Formation at Sierra de Languiñeo, as well as from younger faunal assemblages of the Mojón de Hierro and Río Genoa formations at Sierra de Tepuel and south of José de San Martín Town, respectively (Sabattini and Noirat, 1969; Sabattini, 1978). Finally, Ananias riccardi was previously described from the Pampa de Tepuel Formation at Cerro Mina, Sierra de Languiñeo (Sabattini, 1978; Pinilla, 2012). The bivalves recorded in Sierra de Tecka show a wide stratigraphic distribution in the Tepuel-Genoa Basin from the Pampa de Tepuel Formation to the Río Genoa Formation.

\subsection{The Languigneotus laevicaudatum and Languigneotus-Verchojania subzones}

Most of the taxa described herein have a stratigraphic range that was constrained to the Tuberculatella Zone, a biostratigraphic unit originally described from the Tepuel-Genoa Basin by Simanauskas and Sabattini (1997). This unit is renamed herein as Languigneotus Zone by the reassignment of "Tuberculatella" laevicaudata to the new brachiopod genus Languigneotus, and the recognition of its stratigraphic record as the $L$. laevicaudatum Subzone plus a slightly younger new unit named Languigneotus-Verchojania Subzone (Fig. 3).

Simanauskas and Sabattini (1997) proposed an holostratotype for the "Tuberculatella" Zone just below a layered gabbroid intrusion of the diabase Cresta de los Bosques Formation of Márquez et al., 2001 in the upper part of the lower Tepuel System (section C17) of Suero (1948) (upper half of the Pampa de Tepuel Formation in Sierra de Tepuel). Simanauskas and Sabattini (1997) indicated also two parastratotypes, one at Puesto La Carlota (northern Sierra de Tepuel) and another at Cerro Mina (Sierra de Languiñeo).

The holostratotype of the Languigneotus laevicaudatum Subzone at Sierra de Tepuel underlies glacial-influenced horizons of the uppermost levels of the Pampa de Tepuel Formation, where Amosia sueroi and Tuberculatella laevicaudata, among other invertebrates under study, were preliminary identified (Taboada, 2008). Nevertheless, the systematic affinities of the latter material deserve revision (=Amosia sp.; Languigneotus dammanorum sp. nov. -see below-). Both brachiopods occur in association with Verchojania archboldi in two stratigraphic intervals within the Pampa de Tepuel Formation. One of them is just "above" the gabbroid intrusion of the Cresta de los Bosques Formation at Puesto Tres Lagunas (Sierra de Tepuel) (fossiliferous level 2 of Taboada, 2001; section E21 of Suero, 1948, in part), and the second one represents a thin metric section at the topmost beds cropping out through the Cañadón Lefiú, El Molle area (Taboada, 2008) (uppermost section of the lower part of the Tepuel System of Perrot, 1960). Both intervals are assigned herein to the new Languigneotus-Verchojania Subzone (Fig. 3).

\subsection{Age}

Simanauskas and Sabattini (1997) assigned the Languigneotus laevicaudatum Subzone to the Sakmarian based mainly on the affinities of the gastropod faunas. Subsequently Taboada (2008) discussed this age based on the biostratigraphy and paleontological content of the key stratigraphic section of Puesto La Carlota (parastratotype; fossil-site 7 in Fig. 2) and its correlative holostratotype in Sierra de Tepuel. Changes in faunal composition through levels 3 and 4 (according to terminology of Suero, 1948) of Puesto La Carlota section was emphasized by Hlebszevitsch (2004) and Taboada (2008), who clarified the incoming of the Languigneotus fauna overlying fossil-bearing beds with Verchojania inacayali Taboada, 2008. The fauna of level 3 ("Spirifer" horizon of Suero, 1948) bears key bryozoans such as Australopolypora neerkolensis (Crockford) and Australofenestella stroudensis (Campbell) (Sabattini, 1972, 1986, 2002), as well as Acrocrinidae echinoids (Hlebszevitsch, 2004; Hlebszevitsch and Sabattini, 2005), among other invertebrates (see Taboada, 2008 for full references). This fauna was estimated to be no older than Moscovian-Kasimovian in age, constraining the base of the Languigneotus laevicaudatum Subzone to the early Late Pennsylvanian (late Kasimovian?-Ghzelian). The younger Languigneotus-Verchojania Subzone (=top of the "Tuberculatella" Zone in Taboada, 2008) would be no younger than Asselian, based 
on the known range of Verchojania and because the Cimmeriella fauna of Sakmarian age occurs above (Taboada, 2008; Taboada and Pagani, 2010).

On the other hand, Kasimovian to Asselian maximum ages $(306.05 \pm 3.7 \mathrm{Ma}$ to $301.3 \pm 4.5 \mathrm{Ma})$ were obtained by Griffis et al. (2014) based on $\mathrm{U}-\mathrm{Pb}$ analysis of detrital zircons from shales with dropstones of the Mojón de Hierro Formation at Arroyo Garrido locality (stratigraphically about $1,000 \mathrm{~m}$. above the top of the Languigneotus Zone), representing the younger glacial-related horizon recognized in the Tepuel-Genoa Basin (Taboada et al., 2005; Pagani and Taboada, 2010; Taboada, 2010; Taboada and Shi, 2011). This glacial-related interval overlies fossil-bearing strata with the Cimmeriella fauna and the Glossopteris flora, and underlies beds with Glossopteris and the KochiproductusCostatumulus assemblage, all of them estimated as Cisuralian (Sakmarian-early Artinskian) in age (Taboada, 2010; Taboada and Shi, 2011; Pagani and Taboada, 2011). The maximum U-Pb detrital zircon ages provided by Griffis et al. (2014) do not imply refutation of the younger relative ages suggested by the paleontological studies. Further absolute ages would be desirable in order to constrain and/ or reevaluate the biochronology of the faunal/floral successions as well as the timing of glacial-related intervals and final waning of the Late Paleozoic Ice Age in Patagonia.

\section{Correlation of the Carboniferous of the Arroyo Pescado, Esquel and northern Sierra de Tecka areas}

\subsection{The Arroyo Pescado (Estancia Ap Iwan) deposits}

An unfolded Carboniferous glacial-related section of $127 \mathrm{~m}$ thick was described in Estancia Ap-Iwan by González et al. (1995). The lower two thirds of the succession are characterized by conglomerates, diamictites and shales with dropstones, while the upper third is constituted by sandstones, siltstones and shales. Scarce fossil remains (invertebrates and plants) were recovered from this section, including the ostracode Graphyadactilloides sp. (Díaz Saravia in González et al., 1995), which supporting previous interpretations (Suero, 1948, 1953; Rolleri, 1970) allowed for the recognition of affinities with the Lanipustula patagoniensis Zone of the Pampa de
Tepuel Formation (González et al., 1995; Díaz Saravia and Jones, 1999). Another unit that crops out in the Estancia Ap-Iwan area is the folded, fossilbarren, slightly metamorphosed Arroyo Pescado Formation (Rolleri, 1970), which is less than $100 \mathrm{~m}$ thick (González Bonorino, 1986). It is composed of alternating thin beds of dark grey metasandstones and low-grade quartz-schists, and is separated from the overlying glacial-related section by an inferred angular uncomformity (Rolleri, 1970; Spikermann, 1978). The folding of this section was generally ascribed to the Caledonian orogeny (González, 1985), although some authors suggested that it could have been caused by younger and local tectonic efforts tied to the uprising of the Sierra de Tecka (Vizán et al., 1996). A Rb/Sr age of 349 \pm 29 My has been obtained for the low-grade metamorphic event that affected the Arroyo Pescado Formation (Linares et al., 2001).

\subsection{The Carboniferous of Esquel}

Two folded lithostratigraphic units were proposed for the Carboniferous near Esquel City (Esquel Schists of Feruglio, 1941), the Esquel Formation (Cazau, 1972) and the overlying Valle Chico Formation (Cucchi, 1980). The former has a thickness of $600 \mathrm{~m}$ and is constituted by alternating thin beds of fossil-barren sandstones and shales (López Gamundi, 1980), whereas the latter is about $600 \mathrm{~m}$ thick and shows diamictites, mudstones and siltstones with dropstones and shales containing scarce fossil remains in the lower part ( $80 \mathrm{~m}$ thick), and alternations of dark siltstones and whitish quartzitic sandstones toward the top (López Gamundi, 1980). The contact between these formations was variably interpreted as an angular uncomformity (Cucchi, 1980), erosive (González Bonorino and González Bonorino, 1988) or paracomformable and slightly erosive (herein; Fig. 5). Fossils from the Valle Chico Formation suggest a late Tournaisian age (Taboada et al., 2018), whereas SHRIMP U/Pb data on detrital zircons yielded $372 \pm 9$ My for the base of the unit (Hervé et al., 2005), indicating a maximum late Devonian-Tournaisian age. Consequently, these last ages could be also considered as the minimum age for the Esquel Formation, although discarding a significant hiatus in between (but probably longer than $1 \mathrm{My}$, as estimated by González Bonorino and González Bonorino, 1988). 


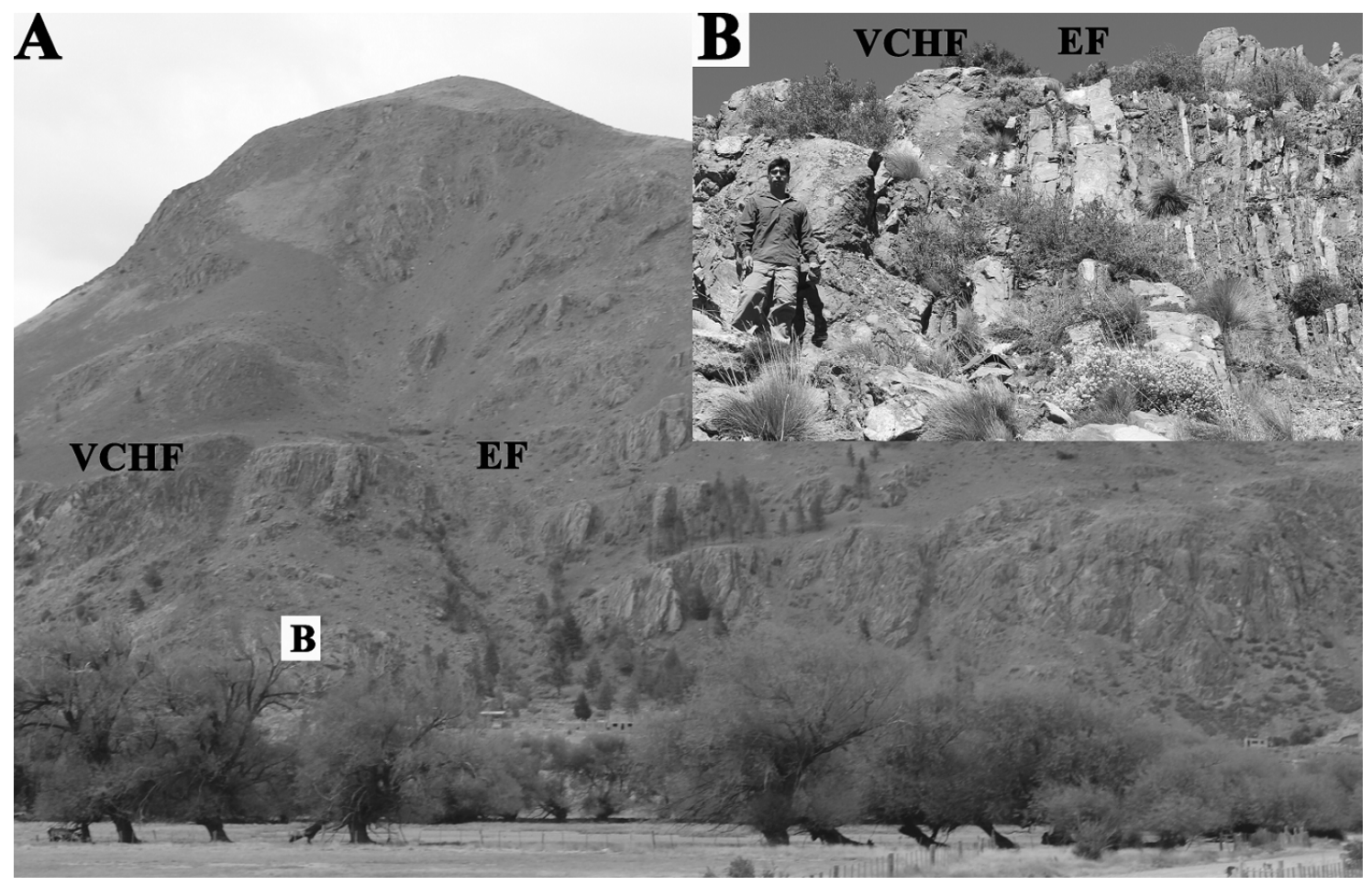

FIG. 5. A. Northeast face of the Cerro Excursión showing outcrops of the Valle Chico (VCHF) and Esquel (EF) formations. B. detail of the paraconformable contact between the uppermost sandstone-shales rhythmites of the Esquel Formation and the basal diamictite of the Valle Chico Formation.

\subsection{Stratigraphic correlations}

The study section at the northern tip of Sierra de Tecka (Quebrada de Güera-Peña) bears a conspicuous fauna which allows to extend further north the Languigneotus laevicaudatum Subzone; a stratigraphic unit that has previously been reported from the Pampa de Tepuel Formation at Sierra de Tepuel, Puesto La Carlota and Sierra de Languiñeo near Colan Conhue Town (Simanauskas and Sabattini, 1997; Taboada, 2008; Pagani and Taboada, 2010).

In addition, recent field work at Estancia ApIwan allowed us to check the stratigraphic schemes proposed by González et al. (1995) and Vizán et al. (1996) for this area. According to our observations, the glacial-related section that crops out there is partially equivalent to the Pampa de Tepuel Formation only from interval D upwards (see description in González et al., 1995), whereas the intervals A, B and $\mathrm{C}$ represent the lower Jurassic conglomeradic beds indicated by Vizán et al. (1996). Based mainly on the occurrence of the ostracod Graphyadactilloides, levels from the Pampa de Tepuel Formation at Estancia Ap-Iwan (Arroyo Pescado area) are older than those of Quebrada Güera Peña.

Additionally, Vizán et al. (1996) regarded the Arroyo Pescado Formation at Estancia Ap-Iwan as equivalent to the Pampa de Tepuel Formation. However, this correlation has not been supported by metamorphic chronology studies. The $\mathrm{Rb} / \mathrm{Sr}$ age of $349 \pm 29$ My determined by Linares et al. (2001) in the Arroyo Pescado Formation accords roughly with the detrital zircon ages obtained at the base of the Valle Chico Formation (Hervé et al., 2005), supporting correlation between the Esquel and Arroyo Pescado formations by its common low grade of metamorphism, as previously suggested by Cucchi (1980). Furthermore, both these units would be, at least in part, equivalents to the southern Río Lácteo/Bahía de la Lancha formations and equivalents (Giacosa and Márquez, 2002 and references therein). Recently, the Llanquihue basement Complex (Hervé et al., 2016) in the subsurface of Los Muermos (Chile, close to $41^{\circ} \mathrm{S}$ ) was considered to be contemporaneous with 
the Esquel and Arroyo Pescado formations, all of them forming an hypothetical late Devonian-early Carboniferous marine basin in the extra-Andean Chubut and southern Chile (Marcos et al., 2017) (Fig. 4).

Correlation of the Esquel Formation with the Arroyo Pescado Formation implies that the former unit should be segregated from the Tepuel Group. Both formations can be regarded as the basement of the glaciomarine column of the Tepuel-Genoa Basin. The overlying Valle Chico Formation represents the basal unit of the Tepuel Group as well as the oldest record of the Late Paleozoic Ice Age in Gondwana.

\section{Summary and conclusions}

The black shales of the Pampa de Tepuel Formation at northern Sierra de Tecka (Quebrada de Güera-Peña) contain diverse fossil assemblages previously listed as belonging to the "Levipustula" fauna. The studied material comprises gastropods [Glabrocingulum (Glabrocingulum) poperimense (Maxwell), G. (Stenozone) argentinum (Reed), G. (Stenozone) sp., Peruvispira teckaensis sp. nov., Ananias riccardii Pinilla], bivalves [Nuculopsis (Nuculopsis) patagoniensis González, Phestia tepuelensis González, Streblochondria sueroi González, Streblopteria sp.], conulariids [Paraconularia cf. ugartei Cúneo and Sabattini], brachiopods [Amosia sueroi Simanauskas, Languigneotus laevicaudatum (Amos), Beecheria patagonica Amos], trilobites [Australosutura argentinensis Hahn and Hahn], cephalopods [Pseudoorthoceratidae Flower and Caster, Sueroceras? sp., Mitorthoceras? sp.], and rugose corals [?Lophophyllidiidae Moore and Jeffords].

In addition, the key brachiopods Languigneotus dammanorum gen. et sp. nov. and Tuberculatella waterhousei sp. nov., from the top of the Pampa de Tepuel Formation and the upper part of the Mojón de Hierro Formation, respectively, are proposed herein.

The Languigneotus laevicaudatum and Languigneotus-Verchojania subzones (late Pennsylvanian) replace the former Tuberculatella Zone. The L. laevicaudatum Subzone would be no older than late Kasimovian?-Ghzelian in age, while the younger Languigneotus-Verchojania Subzone would be no younger than Asselian.

The fauna from northern Sierra de Tecka allows expand further north the Languigneotus laevicaudatum Subzone, a stratigraphic unit that has previously been reported from the Pampa de Tepuel Formation at Sierra de Tepuel, Puesto La Carlota and Sierra de Languiñeo near Colan Conhue Town.

A stratigraphic section cropping out at Estancia Ap Iwan, which was entirely assigned to the Carboniferous by González et al. (1995), includes conglomeradic beds (intervals A-C of González et al., 1995) that are reinterpreted herein as early Jurassic in age, and glacimarine levels (intervals D-H) that are partially equivalent to the Pampa de Tepuel Formation but older than those of Quebrada de Güera-Peña.

On the other hand, a correlation of the Esquel Formation with the Arroyo Pescado Formation and other contemporaneous units (DevonianCarboniferous?) on the paleopacific margin such as the Bahía de la Lancha and Río Lacteo formations, as well as the metamorphic Llanquihue Complex, is assessed (Fig. 4), implying that the Esquel Formation should be segregated from the Tepuel Group. The Esquel and Arroyo Pescado formations can be regarded as the basement of the glaciomarine column of the Tepuel-Genoa Basin.

\section{Paleontological material and methods}

The material studied herein is housed in the Invertebrate Paleontology collections of the Museo Paleontológico Egidio Feruglio, Trelew, Chubut (MPEF-PI); the Laboratorio de Investigaciones en Evolución y Biodiversidad, Esquel, Chubut (LIEBPI); and the Instituto de Paleontología, Fundación Miguel Lillo, San Miguel de Tucumán (FML-IPI). The fossil material was prepared according to standard paleontological procedures (Feldmann et al., 1989). The samples were examined with a stereomicroscope and photographed with a digital camera. The material was coated with magnesium oxide vapors before photographing. Linear measurements were made with Vernier calipers to an accuracy of $0.1 \mathrm{~mm}$.

Several aspects of the suprageneric classification adopted here were discussed by Fortey $(1997,2001)$ for trilobites (MFT); Van Iten et al. (2006) and Leme et al. (2008) for conulariids (CAT); Bouchet and Rocroi (2010) and Carter et al. (2011) for bivalves; Sweet (1964) and Shevyrev (2006) for nautiloids; Hill (1981) for rugose corals (MAP); Bouchet and Rocroi (2005) for gastropods (MKP); and Lee et al. (2007) and Waterhouse (2013) for brachiopod terebratulids and productids, respectively (ACT). Synonymy lists follow the recommendations of Matthews (1973). 
7. Systematic paleontology

Phylum Brachiopoda Duméril, 1806 Order Productida Sarycheva and Sokolskaya, 1959

Suborder Productidina Waagen, 1883

Superfamily Echinoconchoidea Stehli, 1954

Family Sentosiidae McKellar, 1970

Subfamily Tubersulculinae Waterhouse, 1971

(in Bamber and Waterhouse, 1971)

Tribe Lethamiini Waterhouse, 2001

Genus Amosia Simanauskas, 1996

Type species. Amosia sueroi Simanauskas, 1996, from shales north $260^{\circ}$ of "Casa Roelse"

(currently main house of Estancia Entresierras)

of Pampa de Tepuel Formation, Sierra de

Languiñeo (upper section of the lower part

of the "Tepuel System" of Suero, 1948) (late

Pennsylvanian), by original designation.

Remarks: Amosia Simanauskas (1996) was originally placed in the Family Overtoniidae and Subfamily Overtoniinae Muir-Wood and Cooper, 1960. However, Overtoniidae was not used in Brunton et al. (2000), and the genus was relocated in the Tribe Lethamiini Waterhouse, 2001 by Brunton (2007). Amosia was also included in Lethamiini by Waterhouse (2013), although Waterhouse's supratribal hierarchy differs from that used in Brunton (2007). Lethamiini was interpreted as having echinoconchid affinities by the possession of numerous and evenly spaced spines on both valves, and by lacking a special hinge row and a high postero-lateral internal dorsal ridge (Waterhouse, 2013); a criterion that is followed herein.

Amosia sueroi Simanauskas, 1996

Figure 6, A-F

v1960 Productella aff. bifaria (Stainbrock), Amos, p. 91-92, Pl. II, Figs. 7, 8a and 8b 1979 Productella aff. bifaria (Stainbrock), Amos, p. 75-76 (copy from Amos, 1960,

Figs. 7 and 8a)

v*1996 Amosia sueroi Simanauskas, p. 378-380,

Figs. 1, 2A-2H

v.2013 Amosia sueroi Simanauskas;

Waterhouse, p. 193, Figs. 6.16 A-D

Material: Twelve samples, one dorsal valve internal mold, two dorsal valve external molds, one ventral valve internal mold, four ventral valve external molds and four fragmentary articulate specimens.
Geographic and stratigraphic provenance: Specimens LIEB-PI 431-435, from fossil-site 1; MPEF-PI 6194, 6326 from fossil-site 2; LIEB-PI 436-437; LIEB-PI 438-440, from fossil-site 3; LIEB-. PI 441-443 from fossil-site 4; MPEF-PI 6351 from fossil-site 5. All fossil-sites located upstream at right bank of Quebrada de los puestos Güera-Peña, northern Sierra de Tecka (Figs. 2, 4). Pampa de Tepuel Formation, Languigneotus laevicaudatum Subzone. Description: Shell with strongly concave-convex profile, transverse subelliptical outline and average-size for the genus. Maximum width up $24 \mathrm{~mm}$, maximum length up $17 \mathrm{~mm}$, with a $1.42 \mathrm{~W} / \mathrm{L}$ ratio and a hinge line that is equal or slightly shorter than the maximum shell width. Ventral valve strongly convex, with well differentiated ears and margins at right angles. Ornamentation of fine growth lines which are usually sinuous, broad lamellae toward antero-lateral margins and weak rugae on ears. Small slightly prostrate spines irregularly arranged over the whole valve $(4-5 / 5 \mathrm{~mm}$ on the venter) although less densely grouped anteriorly of two concentric rows in a single lamellae close to a short geniculation (Figs. 6D-E). Ears exhibit 2-3 halteroid spines (nearly twice in diameter than venter spines) up $2 \mathrm{~mm}$ length or somewhat longer (Fig. 6C). Ventral valve interior of a juvenile specimen (LIEB-PI 431) with a weak and short median septum laterally bounded at each side by slightly rised diductor scars of drop shape and one third of valve length. Aductor scars unconspicuous. Dorsal valve strongly concave, ornamented with concentric growth lines and weak lamellae anteriorly. Spines are smaller and erected when compared to those of the ventral valve. Few or no spines on the disk, increasing in density $(4-7 / 5 \mathrm{~mm})$ toward anterior and lateral margins with concentric arrangement up two rows in a single lamellae close to the genicule.

Discussion: The profile, outline, dimensions, ornamentation and ventral valve internal features of the studied material collectively indicate affinities with Amosia sueroi Simanauskas, 1996; a species previously described from the Pampa de Tepuel Formation at Sierra de Languiñeo (Simanauskas, 1996) and Sierra de Tepuel (Amos, 1960; Waterhouse, 2013).

Dorsal spine density in the specimens from northern Sierra de Tecka is a little higher than that observed by Simanauskas (1996) in specimens from Sierra de Languiñeo (4-5 spines $/ 5 \mathrm{~mm}$ ). Likewise, the length/width ratio is comparable to that observed in the material from Puesto La Carlota (northern 


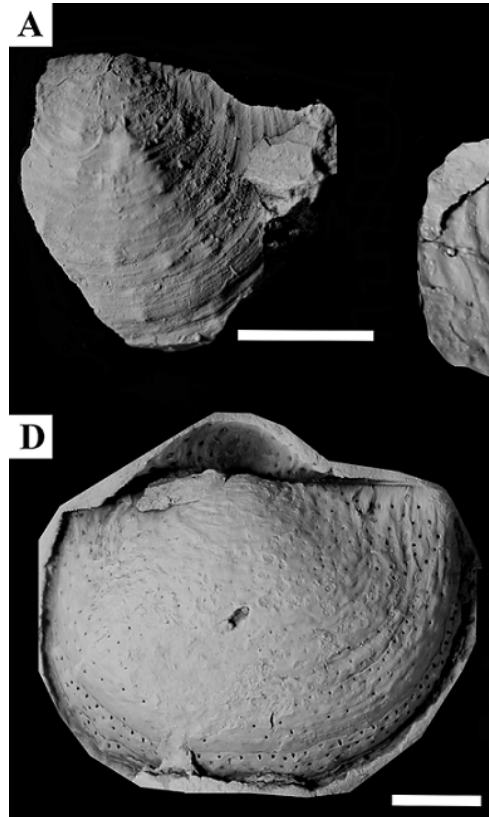

G

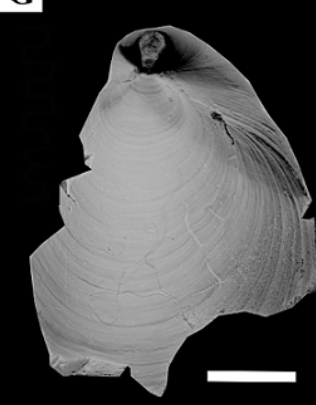

H

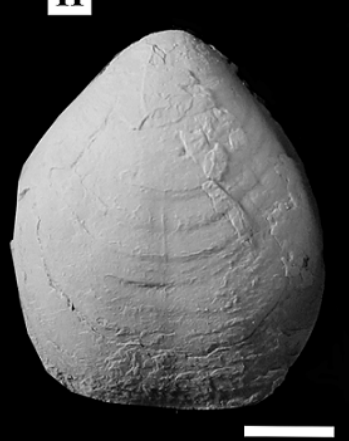

B

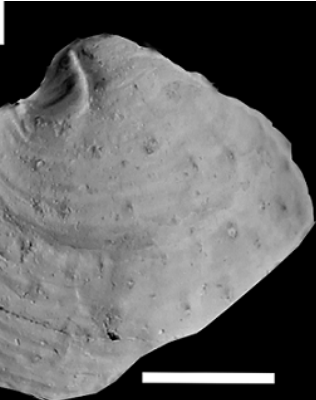

E

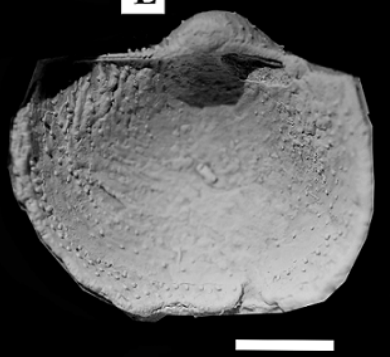

다

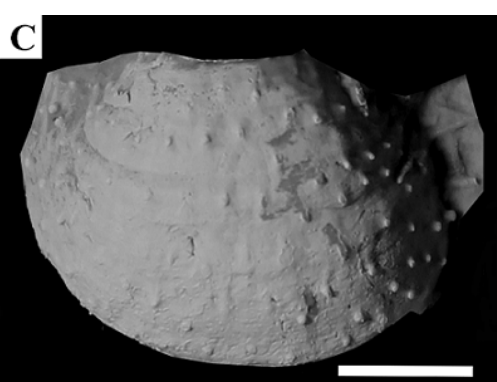

F
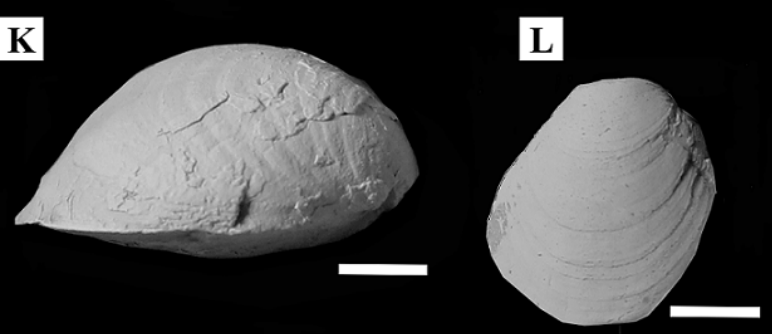

M

I
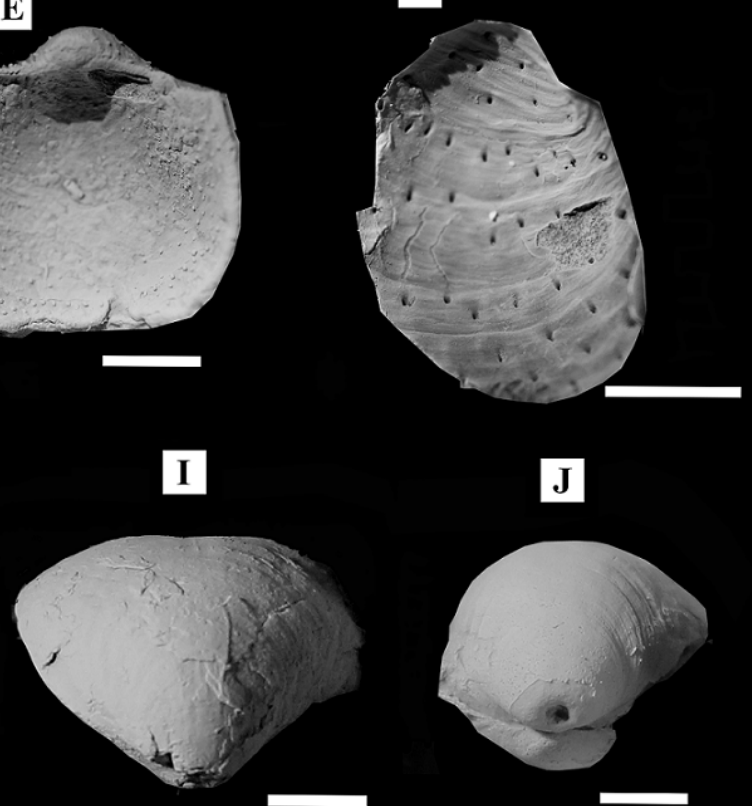

J

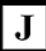


Sierra de Tepuel) by Amos (1960), although higher than the average obtained by Simanauskas (1996) in specimens from Sierra de Languiñeo. Anyway, these values are within the range of variability of the species.

\section{Superfamily Overtonioidea Muir-Wood and Cooper, 1960}

Family Overtoniidae Muir-Wood and Cooper, 1960 Subfamily Overtoniinae Muir-Wood and Cooper, 1960

Genus Languigneotus gen. nov.

Type species. Geniculifera laevicaudata Amos, 1960, from the upper half of Pampa de Tepuel Formation at Cerro Mina (late Pennsylvanian), Sierra de Languiñeo, southwest of Colan Conhué town, by original designation.

Etymology: Combined word derived from the latinized Languiñeo Department, Chubut province, Argentina, and Productus.

Diagnosis: Small to medium-sized shell with a concave-convex profile and a subcircular to subelliptical transverse outline. Hinge line shorter than maximum width of shell. Umbo slightly incurved. Ornamentation of weak irregular concentric rugae, fine growth lines and spines with subcircular slightly swollen bases (2$5 / 2 \mathrm{~mm}$ ), roughly in quincunx arrangement. Dorsal valve with short abrupt geniculation. Ornamentation of concentric irregular rugae stronger than those of ventral valve, fine growth lines, minute subprostrate spines $(4-5 / 2 \mathrm{~mm})$ and subcircular and short elongate dimples. Geniculation with faint growth lines, without spines or constrictions. Cardinal process bilobed externally. Ventral interior with smooth elongate adductors and large diductors striated posteriorly. Dorsal interior with short median septum, smooth adductors and two orders of endospines.

Discussion: The type species of Languigneotus gen. nov. was originally placed in Geniculifera Muir-Wood and Cooper, 1960, based mainly on shell shape and dimensions (Amos, 1960). Nevertheless, doubts on this generic assignment were consigned by Amos (1960), who noted that the type species G. laevicaudata lacks irregular ribs on the geniculation and exhibits dorsal spines. Roberts et al. (1976) indicated that $G$. laevicaudata may belong to Bulahdelia Roberts, 1976 (in Roberts et al., 1976) by having a comparable shape, quincuncially arranged spine bases on the venter of the ventral valve and corresponding dimples on the dorsal valve, and a dorsal valve which is anteriorly geniculate and possesses a similar style of median septum and lateral ridges. Major differences are the smaller ears, the presence of 4 to 5 large erect spines on the auricles, and the apparent absence of rows of suberect spines on the lamellae at the front of both valves of G. laevicaudata (Roberts et al., 1976). Later, Amos (1979) accepted the reassignment of $G$. laevicaudata to Bulahdelia. Finally, Simanauskas (1996) provided a complementary description of the Patagonian species and agreed that G. laevicaudata should be excluded from Geniculifera by the presence of dorsal spines and a smooth geniculation, but rejected its assignment to Bulahdelia by the absence of lamination, and differences in the arrangement of spines and the shell shape. Simanauskas (1996) reassigned G. laevicaudata to Tuberculatella Waterhouse, 1982, though G. laevicaudata slightly differs from the type species T. tubertella Waterhouse, 1982 in shell-size and spine bases, and is clearly distinguished by lacking sinus and having a higher width/length ratio (Simanauskas, 1996). Besides these differences, others of generic significance are related to the geniculation. The material studied herein exhibits a short abrupt geniculation ornamented with just faint concentric lines, and the dorsal valve has an external bifid cardinal process. Because Tuberculatella possesses an external trifid cardinal process, and is ornamented with uneven concentric growth lines disrupted by longitudinal constrictions as anterior ridge-like projections and erect spines on swollen bases, a generic distinction is sustained. The particular combination of characters of the Patagonian material allows propose Languigneotus, a new endemic genus just recorded in the TepuelGenoa Basin. The diagnosis of Languigneotus gen. nov. includes internal characters described for the type species by Simanauskas (1996).

\section{Languigneotus laevicaudatum (Amos, 1960)} Figure 7, A-N

v*1960 Geniculifera laevicaudata Amos, pp. 9294, pl. 2, figs. 1-6

1979 Bulahdelia laevicaudata (Amos), Amos, p.

78, figs. a-c (copy Amos, 1960, figs. 3, 5-6) v.1996 Tuberculatella laevicaudata (Amos), Simanauskas, pp. 381-383, figs. 3a-g

Material: Fourteen specimens, four dorsal valve external molds, five ventral valve external molds, one exterior of ventral valve and fragmentary samples. 
Geographic and stratigraphic provenance: Specimens MPEF-PI 6372 from fossil site-1; MPEFPI 2299 from fossil site-2; MPEF-PI 6324, 6371, from fossil site-3; located upstream at right bank of Quebrada de los puestos Güera-Peña, northern Sierra de Tecka. Specimens LIEB-PI 23a, 23b, 24, 26-27, 29, 132-133, 314, 316, from fossil-site 7, located in a concretionary fossiliferous horizon (= level 4 of Suero, 1948) at $900 \mathrm{~m}$ ENE of Puesto La Carlota, upper half of Pampa de Tepuel Formation (late Pennsylvanian) (Figs. 2, 4). Pampa de Tepuel Formation, Languigneotus laevicaudatum Subzone. Description: Shell of concave-convex and subcircular to slightly transverse subelliptical outline with its maximum width at the posterior third length. Maximun width up to $14.5 \mathrm{~mm}$ and maximum length up to $10.5 \mathrm{~mm}$ with $\mathrm{W} / \mathrm{L}$ ratio varying between $1.18-1.28$. Ventral valve moderately convex with maximum convexity in the posterior third of the valve. Auricles flattened and well differentiated from flanks. Umbo slightly incurved over hinge line. Ornamentation of weak irregular concentric rugae, fine growth lines and spines with subcircular slightly swollen bases. Spines (3-5/2 mm) erect to suberect on auricles and postero-lateral flanks, subpostrate anteriorly, roughly in quincunx arrangement, more abundant toward the anterior half of the valve. With two hinge spines on each side of the umbo (up to $4 \mathrm{~mm}$ length) and other two larger ones on the auricles. Dorsal valve weak to moderately concave with short geniculation at $\sim 90^{\circ}$. Ornamentation of concentric irregular rugae stronger than those of ventral valve, fine growth lines, minute spines and subcircular to short elongate dimples. Spines (4-5/2 $\mathrm{mm})$ located between dimples in a roughly concentric pattern, subprostrated to prostrated anteriorly. Geniculation with faint growth lines, without spines or constrictions. Cardinal process bilobed, externally bifid. Internal characters unknown.

Discussion: Specimens from Quebrada de GüeraPeña and Puesto La Carlota colectivelly show all the diagnostic characters first described by Amos (1960) for L. laevicaudatum (Amos) and later reviewed by Simanauskas (1996). They share a concave-convex and subcircular to slightly transversely subelliptical outline with its maximum width at the posterior third of the shell, and strong geniculation. The ventral valve exhibits ornamentation of weak irregular concentric rugae, as well as fine growth lines and spines with subcircular slightly swollen bases, roughly in quincunx arrangement. The dorsal valve is ornamentated with concentric irregular rugae that are stronger than those of the ventral valve, fine growth lines, minute spines and subcircular to short elongate dimples.

Some specimens from Quebrada de GüeraPeña exhibit more concave dorsal valves which are attributed to intraspecific variations. Simanauskas (1996) reported material of L. laevicaudatum from Puesto La Carlota locality but it was not described nor figured.

\section{Languigneotus dammanorum gen. et sp. nov. Figure 8, A-E}

Material: Three specimens, two dorsal valve external molds and one ventral valve external mold.

Holotype: FML-IPI 3879

Paratypes: FML-IPI 3877, 3880

Geographic and stratigraphic provenance: Specimens FML-IPI 3877, 3879 and 3880 from fossil-site 9 , located in a pebbly sandstone bed overlying glaciomarine deposits of the upper part of Pampa de Tepuel Formation at El Molle area, $1 \mathrm{~km}$ to the east of Puesto Lefiú (Fig. 2). Pampa de Tepuel Formation, Languigneotus-Verchojania Subzone (early? Asselian).

Etymology: Combined three first letters of the last names of the outstanding paleontologists Professors Susana Damborenea and Miguel Manceñido (University of La Plata, Argentina).

Diagnosis: Medium-sized shell of weakly concaveconvex profile and slightly elongate subcircular outline. Hinge line shorter than maximum width of shell. Umbo incurved over hinge line. Ornamentation of concentric rugae, fine growth lines, subprostrate to prostrate spines $(2-3 / 2 \mathrm{~mm})$ and dimples on dorsal valve.

Description: Shell of weakly concave-convex profile and slightly elongate subcircular outline. Maximum width up $15 \mathrm{~mm}$ and maximum length up $14 \mathrm{~mm}$ with $\mathrm{W} / \mathrm{L}$ ratio between 1.07-1.16. Hinge line of $3 / 4$ of maximum width which is located at mid-length of the shell. Umbo incurved over hinge line. Ventral valve moderately convex with maximum convexity at the posterior third of the valve. Ornamentation of regular concentric rugae, fine growth lines, subprostrate spines of flanks and auricles and prostrate spines anteriorly. Spines on slightly swollen elongate bases $(2-3 / 2 \mathrm{~mm})$ arranged in a roughly quincuncial pattern. Dorsal valve weakly concave, flattened toward auricles and laterally, with obtuse cardinal angles and short 


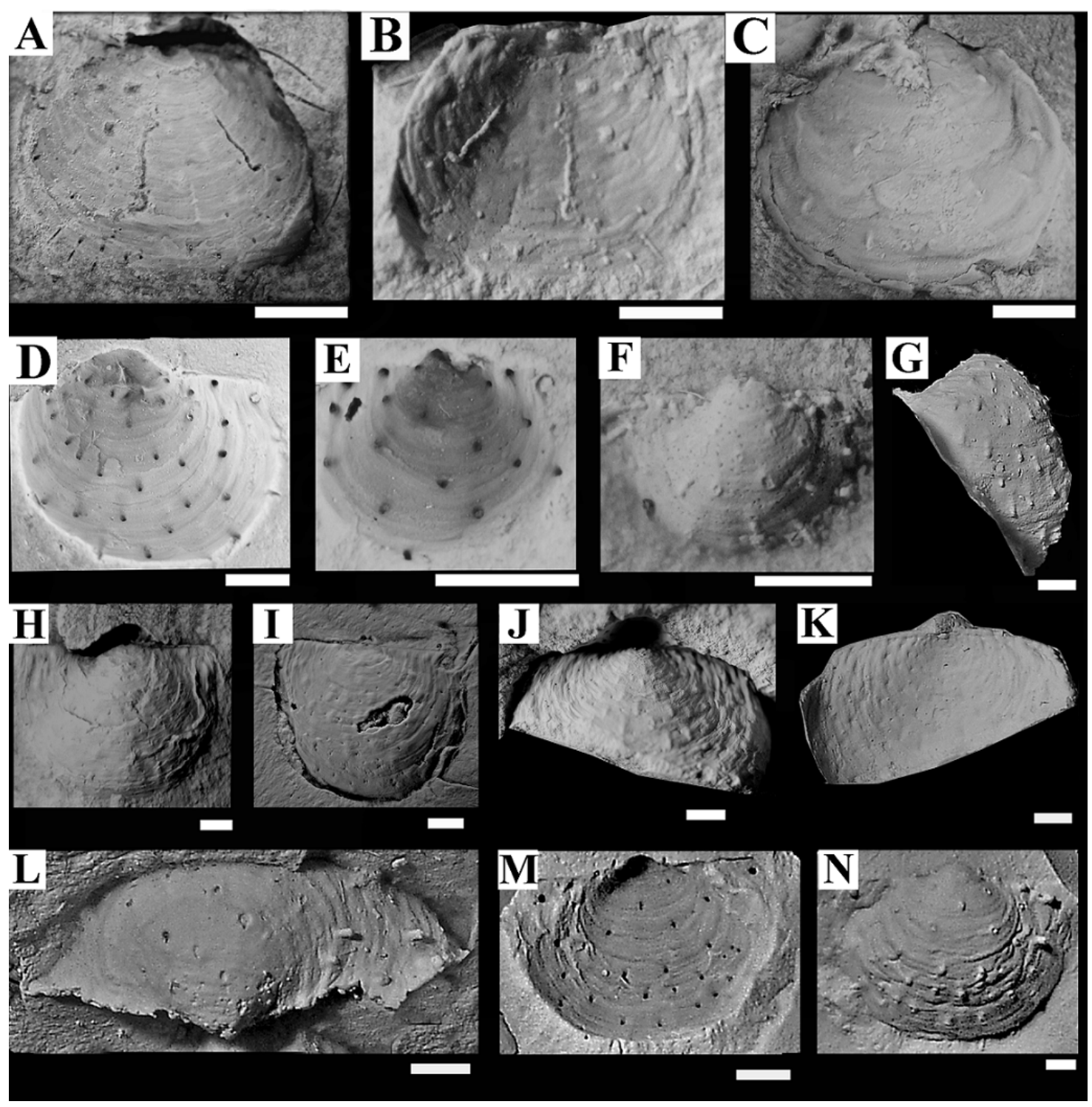

FIG 7. A-N. Languigneotus laevicaudatum (Amos, 1960); A-F. Specimens from Quebrada de Güera-Peña. A-B. Dorsal valve external mold and its polyvinilxyloxane cast, MEF-PI 6324 C. Ventral valve exterior, MEF-PI6372; D. External mold of ventral valve, MEF-PI 2299; E-F. External mold of ventral valve and its polyvinilxyloxane cast, MEF-PI 6371; G-N. Specimens from La Carlota; G. Polyvinilxyloxane external ventral valve cast, LIEB-PI 23a; H. Dorsal valve external mold, LIEB-PI24; I. Dorsal valve external mold, LIEB-PI 26; J-K. External mold of fragmentary articulate specimen showing geniculate dorsal valve and ventral umbonal region, and its polyvinilxyloxane mold, LIEB-PI 23b; L. Polyvinilxyloxane external ventral valve cast, LIEB-PI 27; M-N. Ventral valve external mold and its polyvinilxyloxane cast, LIEB-PI 133. Scale bar: $5 \mathrm{~mm}$. 


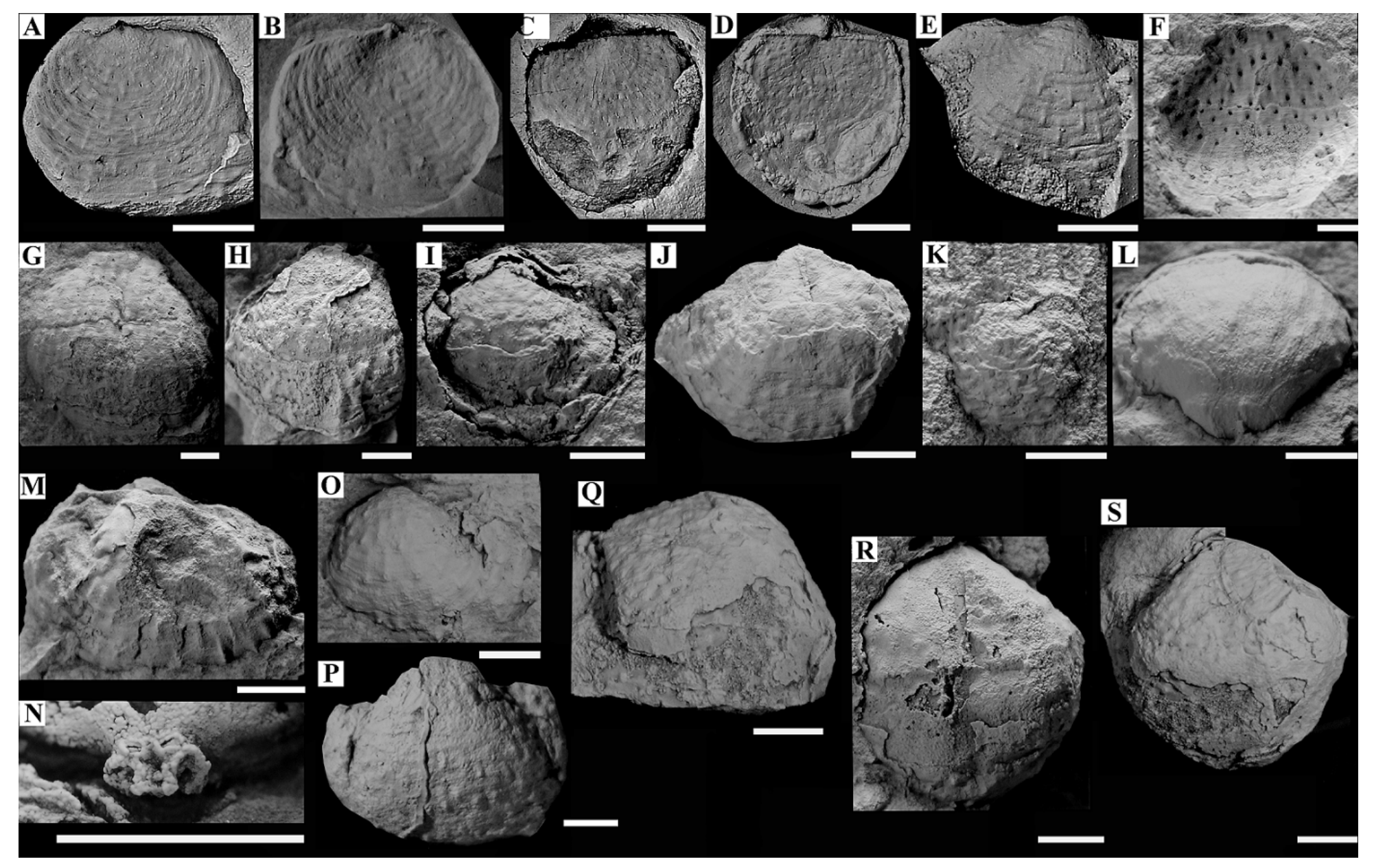

FIG 8. A-E. Languigneotus dammanorum sp. nov.; A-B. Dorsal valve external mold and its polyvinilxyloxane cast, FML-IPI 3877; C-D. Dorsal valve external mold and its polyvinilxyloxane cast, FML-IPI 3879; E. Polyvinilxyloxane external ventral valve cast, FML-IPI 3880; F-S. Tuberculatella waterhousei sp. nov.; F-G. Ventral valve external mold, LIEB-PI 302a; H. Dorsal valve external mold, LIEB-PI 305; I, N. Dorsal valve external mold and detail of cardinal process, LIEB-PI 307; J. Dorsal valve external mold, LIEB-PI 306; K. Dorsal valve external mold, LIEB-PI 308; L. Ventral valve internal mold in postero-ventral view, LIEB-PI 309; M. Ventral valve external mold, LIEB-PI 304; O. Polyvinilxyloxane external ventral valve cast, LIEB-PI 312; P. Polyvinilxyloxane external ventral valve cast, LIEB-PI 302b; Q, S. Dorsal valve external mold in lateral and ventral view, LIEB-PI 303; R. Ventral valve internal mold, LIEB-PI 310 . Scale bar: $5 \mathrm{~mm}$, except for figure $\mathrm{N}:=2 \mathrm{~mm}$. 
geniculation at $\sim 80^{\circ}$ (Figs. $8 \mathrm{C}$-D). Ornamentation of weak concentric rugae on auricles and laterally (almost imperceptible on disc), fine growth lines, minute subprostrate spines and elongate dimples. Spines with a roughly quincuncial arrangement located between dimples, with a density of 2-3/2 mm. Discussion: Languigneotus dammanorum gen. et $\mathrm{sp}$. nov. is close to L. laevicaudatum (Amos), but the shell of the former exhibits a less transverse shape, a shorter hinge line, a weakly concave to flattened dorsal valve, an umbo which is located above the hinge line, and a lower spine density. Taboada (2008) and Pagani and Taboada (2010) mentioned the presence of "Tuberculatella?" laevicaudata (Amos), here classified as Languigneotus dammanorum sp. nov., in association with Verchojania archboldi characterizing the top of the "Tuberculatella" Biozone, here the Languigneotus-Verchojania Subzone.

\section{Family Avoniidae Sarytcheva, 1960 Subfamily Avoniinae Sarytcheva, 1960 Genus Tuberculatella Waterhouse, 1982 Type species: Tuberculatella tubertella Waterhouse, 1982, from Luak Formation (Moscovian), Huai Bun Nak, Loei, north Thailand, by original designation.}

\section{Tuberculatella waterhousei sp. nov. Figure 8, F-S}

Material: Thirteen specimens, four ventral valve external molds, seven dorsal valve external molds and two ventral valve internal molds.

Holotype: LIEB-PI 302a

Paratypes: LIEB-PI 302b, 307, 309

Additional material: LIEB-PI 303-306, 308, 310-312 Geographic and stratigraphic provenance: Specimens LIEB-PI 302-312, from fossil-site 8, located $4 \mathrm{~km}$ to the east of Puesto Tres Lagunas, Sierra de Tepuel, upper part of Mojón de Hierro Formation (level 6 of Taboada, 2001) (Fig. 2), Cimmeriella-Costaumulus Zone (late Sakmarian).

Etymology: In honor of the New Zealand Professor Bruce Waterhouse, outstanding paleontologist and expert on biostratigraphy.

Diagnosis: Average to large-sized shell of strong concave-convex profile and subelliptical transverse outline. Ventral valve with long trail. Hinge line shorter than maximum width of shell. Ornamentation of concentric growth lines, suberect spines on swollen oval bases on venter and flanks, and erect spines on auricles and trail. Dorsal valve gently concave in the visceral disc, with relatively long geniculation. Ornamentation of weak concentric rugae, uneven growth lines, deep dimples, and among them, small erect spines over the whole valve. Concentric uneven growth lines disrupted by longitudinal constrictions on trail. Cardinal process bilobed, externally trifid. Description: Average to large-sized shell for the genus, with maximum width and length exceeding $29 \mathrm{~mm}$ and $26 \mathrm{~mm}$, respectively. Shell of strong concaveconvex profile and subelliptical transverse outline, with a W/L ratio average of 1.25 . Ventral valve of moderate convexity on venter, with long trail near the geniculation $\left(\sim 60^{\circ}\right)$. Hinge line shorter than maximum width which is located at valve mid-length. Umbonal angle close to $90^{\circ}$, auricles slightly convex and well differentiated from flanks. Median sinus variably developed, narrow, shallow anteriorly, not reaching the commissure. Ornamentation of concentric growth lines (less regular anteriorly), suberect spines on swollen oval bases on venter and flanks, and erect spines on auricles and trail. Spines in quincuncial arrangement, in number of 4-5/5 $\mathrm{mm}$ on venter increasing to 5-6/ $5 \mathrm{~mm}$ on trail. Maximum diameter average of spine bases near $1 \mathrm{~mm}$ on venter, decreasing to half on trail. Irregular growth constrictions on trail rise as ridge-like longitudinal proyections disrupting wellmarked concentric ornamentation. Ventral interior with smooth oval adductors ( $4 \mathrm{~mm}$ length and $2.5 \mathrm{~mm}$ width) separated by a thin myophragm. Diductor scars (5.5 mm length) drop-shaped, weakly radially grooved, reaching $2 / 5$ of valve length. Rest of valve surface with small, radially aligned pustules. Dorsal valve gently concave on the disc, with a relatively long geniculation at $\sim 60^{\circ}$. Dorsal fold variably developed, shallow or absent. Ornamentation of weak concentric rugae, uneven growth lines, deep dimples, and among them, small erect spines over the whole valve $(\sim 15 / 5 \mathrm{~mm})$ in roughly quincuncial arrangement. Concentric uneven growth lines disrupted by longitudinal constrictions on trail. Cardinal process bilobed, externally trifid.

Discussion: Some specimens described herein were preliminary assigned to Tuberculatella by Dr. B. Waterhouse during an international workshop in Patagonia in 2009 (see Taboada et al., 2009). The shell shape and diagnostic ornamentation of this genus are herein confirmed, while the dimensions, shell outline, geniculation, and density and characteristcs of the spines, allow us to propose a new species. Although 
the type species, T. tubertella was originally described as having a bifid cardinal process (Waterhouse, 1982), this character, like in the Patagonian species, seems to be trifid, as shown in the illustrations of the holotype (Waterhouse, 1982, 2013; Brunton, 2007). T. waterhousei sp. nov. also resembles $T$. tubertella in sharing a transverse shell outline, a similar spine pattern, and irregular longitudinal ridge-like projections anteriorly, but the former species is differentiated mainly by the presence of more elongate spine bases on the ventral valve and more numerous spines on both valves.

Avonia karpinskiana (Yanischevsky) (Sarytcheva, 1968), from the middle to late Carboniferous of the Urals, Verchojan (Russia) and Kazhakstan regions, was included in Tuberculatella by Waterhouse (1982). The Russian species exhibits a hinge line that is coincident with the maximum width of the shell, and prominent ventral spine bases, unlike $T$. waterhousei sp. nov. Another species assigned to Tuberculatella by Waterhouse (2013) is Maemia archboldi Martínez Chacón and Winkler Prins (2008) from the Valdejeta Formation (Bashkirian) of Asturias, northern Spain. Nevertheless, the presence of a slightly elongate shell profile, ribs which are weak and restricted to the anterior part of the trail or absent, short spine bases, lamellose irregular rugae on both valves, and an externally bifid cardinal process, prevent an assignment to Tuberculatella.

Specimens from central-western Argentina (Uspallata-Iglesia Basin) were ascribed to Tuberculatella by Simanauskas and Cisterna (2001). These authors referred Productus (Marginifera) spinulo-costatus Abich var. peregrina Reed (1927), from the Pituil Formation (=Esquina Gris Formation, in part, Taboada, 1997), to Tuberculatella, together with specimens from the lower fossil-bearing interval of the El Paso Formation (Simanauskas and Cisterna, 2001). Furthermore, Simanauskas and Cisterna (2001) included Bulahdelia cf. B. myallensis Roberts of Taboada (1989; see also Taboada et al., 2009; Taboada, 2010) in the synonymy of "Tuberculatella peregrina (Reed, 1927)". Although this concept of "Tuberculatella peregrina (Reed, 1927)" was followed until recently by Cisterna and Sterren (2016) and Cisterna et al. (2017), a different taxonomic viewpoint was suggested by Taboada $(1997,2006)$. Material of $P$. (M.) spinulo-costatus var. peregrina from the Pituil Formation has a ventral valve that is moderately convex, transversely subelliptical in outline with a hinge line equal or nearly equal to the maximum width, without geniculation. It is ornamented with concentric growth lines and weak, low, rounded ribs which are somewhat discontinuous mainly due to the presence of regular radially elongate recumbent stout spines arranged in a roughly quincunx style. Auricles bear 2-3 spines and other 3-5 aligned at the junction of the auricles and the flanks (Reed, 1927). All these characters indicate that this material is conspecific with Maemia tenuiscostata (formerly Geniculifera tenuiscostata of Taboada, 1997; see also Taboada et al., 2009; Taboada, 2006, 2010).

On the other hand, specimens from the El Paso Formation ascribed to "Tuberculatella peregrina" by Simanauskas and Cisterna (2001) exhibit a smooth geniculation in both valves or faint growth lines (Cisterna et al., 2017). This character contrasts with Reed's var. peregrina which lacks ventral geniculation, as well as with Tuberculatella which shows irregular longitudinal constrictions on dorsal and ventral genicule, and with $B$. cf. B. myallensis which has a spinose tuberculate trail. The general morphology of the El Paso's specimens is comparable to that of Languigneotus gen. nov., but the presence of strong irregular lamellose rugae and a conspicuous geniculation on both valves, coupled with robust grooved diductors and dorsal rised adductors, may justify the erection of a new genus.

\section{Order Terebratulida Waagen, 1883}

Suborder Terebratulidina Waagen, 1883

Superfamily Dielasmatoidea Schuchert, 1913

Family Beecheridae Smirnova, 2004

Genus Beecheria Hall and Clarke, 1893

Type species. Beecheria davidsoni Hall and

Clarke, 1893, from the Viséan Windsor Group, Nova Scotia, Canada.

\section{Beecheria patagonica Amos, 1958} Figure 6, G-N

*1958 Beecheria patagonica Amos, pp. 104-106, fig. 2, 1-8

1979 Beecheria patagonica Amos; Amos, p. 95, figs. a-c (copy Amos, 1958, only Figs. 6-7).

2016 Beecheria patagonica Amos; Cisterna and Sterren, figs. 5, R-S

2017 Beecheria patagonica Amos; Cisterna, Sterren, López Gamundi and Vergel, pp. 15-16, figs. 5, D-F (copy Cisterna and Sterren, 2016, Figs. 5, only R-S) 
Material: Twelve samples, one articulate specimen, two external molds of articulate specimens, four external molds of ventral valves and fragmentary remains.

Geographic and stratigraphic provenance: Specimens MPEF-PI 3064, 3067, 6221, 6250, 6252, $6254,6257,6259,6312,6352$ from fossil-site 2; MPEF-PI 6182, 6256, 6258, 6317, 6319, 6323, 6325 from fossil-site 3 . All fossil-sites located upstream at right bank of Quebrada de los puestos Güera-Peña, northern Sierra de Tecka. (Figs. 2, 4). Pampa de Tepuel Formation, Languigneotus laevicaudatum Subzone (late Pennsylvanian).

Description: Medium-size shell up $22 \mathrm{~mm}$ in length, $19.5 \mathrm{~mm}$ in width and $11 \mathrm{~mm}$ in thickness. Shell unequally biconvex with a slightly elongate subelliptical outline and maximum width at valve midlength. Ventral valve more convex than dorsal valve, umbo nearly straight to suberect and umbonal angle near $95^{\circ}$. Ventral valve with a weak shallow depression on anterior half. Commissure rectimarginate. Shell smooth with concentric growth lines and lamellae. Foramen subpermesothyrid. Dental plates slightly divergent, anterior- and ventrally. Punctae densely and regularly arranged.

Discussion: According to the above description, the specimens studied are confidently assigned to Beecheria patagonica Amos, 1958. This species was originally described from the Languigneotus laevicaudatum Subzone of the Pampa de Tepuel Formation at Languiñeo and Tepuel hills (Amos, 1958). Beecheria patagonica was also reported from several localities of central-western Argentina (Uspallata-Iglesia Basin) (Amos, 1958, 1979 and references therein) and eastern Australia (Yarrol Basin) (Beecheria aff. patagonica of Campbell and McKellar, 1969), but was only discussed and illustrated from the El Paso Formation (Cisterna and Sterren, 2016; Cisterna et al., 2017). Beecheria sp. from the Hoyada Verde Formation (Uspallata-Iglesia Basin) (Cisterna and Sterren, 2016), as well as Beecheria boranelensis and Beecheria subrotundatus Peou and Engel, 1979, from the Faulkland Formation, New South Wales, Australia, have a well- developed dorsal median septum, unlike Beecheria patagonica Amos.

Class Gastropoda Cuvier, 1795 Clade Vetigastropoda Salvini-Plawen, 1980 Superfamily Eotomarioidea Wenz, 1938 Family Eotomariidae Wenz, 1938
Subfamily Eotomariinae Wenz, 1938

Tribe Glabrocingulini Gordon and Yochelson, 1987

Genus Glabrocingulum Thomas, 1940

Subgenus Glabrocingulum (Glabrocingulum) Thomas, 1940

Type species. Glabrocingulum beggi Thomas, 1940, from the Viséan of Scotland, by original designation.

Remarks: The genus Glabrocingulum was originally described by Thomas (1940) and has a total stratigraphic range from the Carboniferous to the Permian. It is known from Europe, North America, South America, Australia and Asia. Sloan (1955) divided the genus and regarded the subgenus $G$. (Glabrocingulum) as an eotomariid having a turbinate shell; a straight upper surface; a convex outer lower face; a concave peripheric selenizone; and spiral and transverse lines on upper and lower surfaces, with small nodes or pustules at the intersections of both systems of lines. The pleural angle varies from $70^{\circ}$ to $120^{\circ}$, and the base is convex and phaneronphalous.

\section{Glabrocingulum (Glabrocingulum) poperimense (Maxwell, 1964) \\ Figure 9, A-B, E \\ *1964 Pseudobaylea poperimensis sp. nov. \\ Maxwell, p. 21-22, Pl. 4, figs. 12-17 \\ v1969 Mourlonia (Pseudobaylea) poperimensis \\ Maxwell; Sabattini and Noirat, p. 101-102, Pl. \\ 1, figs. 3-4}

Material: Twenty-one fragmentary external and internal molds in concretionary samples.

Geographic and stratigraphic provenance: MPEF-PI $6261,6263,6265,6266,6268$ and 6269 from fossil site-2; MPEF-PI 6286-6288, 6272, 6274, 6277, 6290, 6291, 6297, 6298, 6301, 6303, 6304 and 6315 from fossil site-3; MPEF-PI 6308, 6311, 6333, 6360-6362, 6366-6367 and 6369 from fossil site-5. All fossil-sites located upstream at right bank of Quebrada de los puestos Güera-Peña, northern Sierra de Tecka (Figs. 2, 4), Pampa de Tepuel Formation, Languigneotus laevicaudatum Subzone (late Pennsylvanian).

Description: The specimens examined are characterized by having a turbiniform shell with a pleural angle of $93^{\circ}$ to $100^{\circ}$, and an inclined and flat upper whorl surface. The selenizone is concave in profile, narrow (0.3$1.0 \mathrm{~mm}$ width), and has a peripheric position; it is bounded by two spiral cords, and shows numerous, 

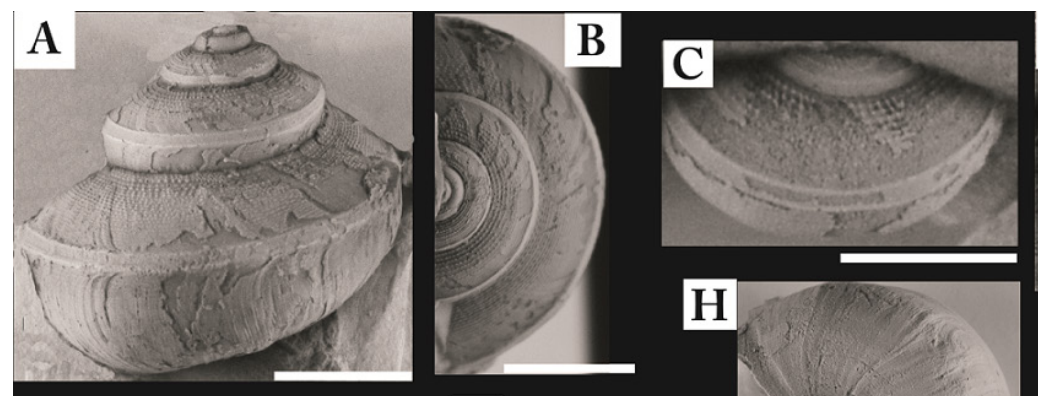

\section{D}

H

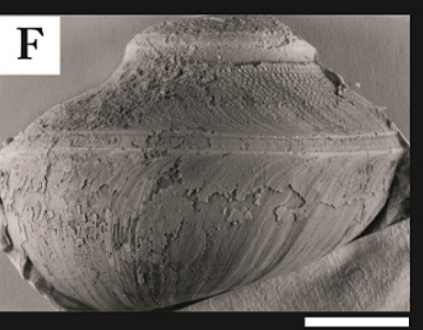

G

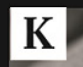

K
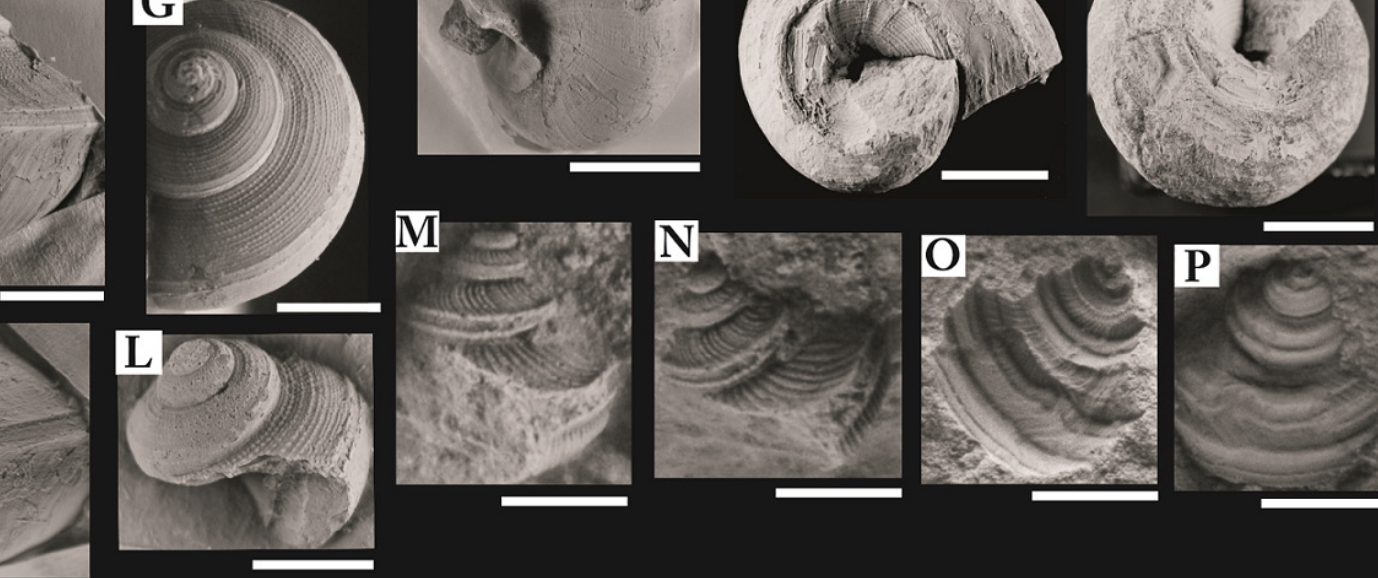

FIG 9. A-B, E. Glabrocingulum (Glabrocingulum) poperimense (Maxwell); A, MEF 1859, latex mould of shell showing four whorls and nodose spiral ornamentation; B. MEF 1859, latex mould, apical view; detail of well-marked nodose spiral lirae on upper whorl face; E. MEF 1866(b), latex mould, lateral view of five whorls; detail of the closely spaced nodose spiral lirae and selenizone. C-D, G, L. Glabrocingulum (Stenozone) argentinum (Reed); C. MEF 1769, latex mould, last whorl in apical view showing ornamentation and selenizone; D. MEF 1769 , latex mould in lateral view showing the selenizone bounded by two spiral cords, and spiral threads on outer whorl face; G. MEF 1871, latex mould, apical view of five whorls with details of the upper whorl surface and nodose spiral lirae; L. MEF 1755, external latex mould of four whorls; apical view showing nodose spiral threads on the upper whorl surface, and a concave, peripheric selenizone. F, H, K. Ananias riccardii Pinilla; F. MEF 1834, latex mould, lateral view of last two whorls with details of the spiral lirae on the upper whorl face, the selenizone, and growth lines on the outer surface; $\mathbf{H}$. MEF 1872, latex mould of phaneronphalous shell base showing spiral and collabral treads; K. MEF 1834 , external latex mould of last whorl in lateral view; detail of the selenizone. I-J. Glabrocingulum (Stenozone) sp. 1; I. MEF 1792, external mould in apical view; detail of the upper whorl surface and nodose spiral ornamentation; J. MEF 1792, lateral view of outer whorl surface. M-P. Peruvispira teckaensis sp. nov.; M. MEF 1796, external latex mould in lateral view; detail of the last whorl showing a concave selenizone, faint alveozone, anonphalous shell base and collabral ornament; N. MEF 1796, holotype, external latex mould in lateral view; detail of collabral lirae on the upper whorl face; O, MEF 1847, paratype, fragmentary external mould showing a detail of the collabral ornamentation; P. MEF-1847, external latex mould showing shell surface and closely spaced collabral lirae. Scale bars: $10 \mathrm{~mm}$ (Figures A-B, E-K) and $5 \mathrm{~mm}$ (Figures C-D, L-P). 
fine lunulae. The outer whorl face is convex. The ornamentation consists of spiral and transverse elements bearing small nodes at crossing points. The spiral lirae are well marked, with 11 to 16 nodose elements on the upper whorl face. The outer face below the selenizone, and the base have 20 spiral elements. The base is convex and phaneromphalous, and spiral nodose elements rise over the growth lines.

Discussion: These specimens fit with material from the Tepuel-Genoa Basin (La Carlota, Tres Lagunas, El Molle, Quebrada Honda, Salar de Ferrarotti and Languiñeo Hills) that was previously assigned to Mourlonia (Pseudobaylea) poperimensis by Sabattini and Noirat (1969). Based mainly on the presence of a turbiniform shell, a transverse and revolving ornamentation, and a concave, narrow and peripheric selenizone, this species is reassigned herein to $G$. (Glabrocingulum).

G. (G.) poperimense closely resembles two North American species, G. (G.) granulosum Gordon and Yochelson (1987) and G. (G.) quadrignatum Sadlick and Nielsen (Gordon and Yochelson, 1987) from the Mississippian of Utah, USA. However, $G$. $(G$.) granulosum differs by having spiral nodose lirae of two sizes on the body whorl, whereas $G$. (G.) quadrignatum exhibits 5-7 spiral nodose elements on the upper whorl surface (versus 11-16).

$G$. (G.) poperimense also shows similarities with $G$. (G.) amotapense Thomas (Newell et al., 1953), from the middle Pennsylvanian of the Tarma Group, Peru, which possesses a similar pleural angle, a flat upper whorl face, and a convex outer whorl face. The Peruvian species hardly differs by having a smaller number of spiral cords on the body whorl.

G. (Glabrocingulum) poperimense and $G$. $(G$.) hosei Gordon and Yochelson (1987), from the late Mississippian (Paracravenoceras barnettense Zone and Cravenoceras hesperium Zone) of Utah, USA, share a similar prominence of the spiral sculpture and a concave, peripheric selenizone; however, $G$. (G) hosei differs by having a pleural angle of $88^{\circ}$ (versus $93^{\circ}-100^{\circ}$ ) and an anonphalous shell base.

Subgenus Glabrocingulum (Stenozone) Batten, 1972 Type species: Glabrocingulum (Stenozone) nodosuturala Batten, 1972, from the lower Permian of Malaysia, by original designation.

\section{Glabrocingulum (Stenozone) argentinum (Reed,} 1927)
Figure 9, C-D, G, L

*1927 Pleurotomaria argentina Reed (in Du

Toit, p. 144, pl. 15, figs. 3 a-c)

1955 Glabrocingulum argentinus (Reed), Sloan, p. 278

v1969 Glabrocingulum argentinus (Reed), Sabattini and Noirat, p. 102-112, pl. 1, fig. 5 1972 Glabrocingulum (Stenozone) argentinus (Reed), Batten, p. 21

1978 Glabrocingulum (Stenozone) argentinus (Reed), Sabattini, p. 49-51

1979 Glabrocingulum (Stenozone) argentinus (Reed), Amos, p 149, fig. 1 (copy

Sabattini and Noirat, 1969, pl. 1, fig. 5)

1980 Glabrocingulum (Stenozone) argentinus (Reed), Sabattini, p. 112

1987 Glabrocingulum (Stenozone) argentinus (Reed), Cúneo and Sabattini, p. 292

Material: Three external molds. Geographic and stratigraphic provenance: $M P E F-$ PI 6260, 6267 from fossil site-1; MPEF-PI 6299 from fossil site-4; all fossil-sites located upstream at right bank of Quebrada de los puestos Güera-Peña, northern Sierra de Tecka (Figs. 2, 4), Pampa de Tepuel Formation, Languigneotus laevicaudatum Subzone (late Pennsylvanian).

Description: The specimens studied show a turbiniform shell with five whorls, a pleural angle of $91^{\circ}-120^{\circ}$, and an inclined and flat upper whorl surface. The ornamentation consists of 11-13 wellmarked spiral nodose elements which are intersected by prosocline growth lines. The selenizone is narrow (0.4-0.8 $\mathrm{mm}$ width) and concave, peripheral in position. The outer whorl face is gently convex and the base is rounded, phaneronphalous, with prominent spiral nodose elements and faint growth lines.

Remarks: According to the revision of Sabattini and Noirat (1969), these specimens are assignable to Glabrocingulum (Stenozone) argentinum (Reed, 1927); a species known from classic localities from the Tepuel-Genoa Basin (Tres Lagunas, El Molle, Quebrada Honda, Languiñeo Hills and La Carlota), as well as from the Calingasta-Uspallata Basin, western Argentina (Sabattini, 1980).

$G$. (S.) argentinum (Reed, 1927) strongly resembles G. (S.) elegans Swart (1998), from the Kungurian of the Carnavon Basin, West Australia, by sharing spiral lirae intersecting collabral growth lines making a characteristic pattern of nodes, and a pleural angle 
of $124^{\circ}$; however, the Australian species bears a selenizone which is not bounded by spiral elements, so it is perceptible only by the deflection of growth lines.

\section{Glabrocingulum (Stenozone) sp. 1 Figure 9, I-J}

Material: Six fragmentary external molds. Geographic and stratigraphic provenance: MPEF-PI 6309 from fossil site-1; MPEF-PI 6264, 6270 from fossil site-2; MPEF-PI 6273, 6278, 6289 from fossil site-3. All fossil-sites located upstream at right bank of Quebrada de los puestos Güera-Peña, northern Sierra de Tecka (Figs. 2, 4), Pampa de Tepuel Formation, Languigneotus laevicaudatum Subzone (late Pennsylvanian).

Description: External molds of the shell with five whorls; upper whorl surface flattened, inclined, bearing nodose spiral lirae; selenizone peripheric, narrow (0.7$0.9 \mathrm{~mm}$ width) and concave, bounded by two spiral treads; outer whorl face with opistocline growth lines below selenizone; base convex, phaneronphalous.

Discussion: The material described above closely resembles Glabrocingulum (Stenozone) brennensis Reed (Batten, 1972), from the early Permian of Malasya, in sharing nodose spiral elements on the upper whorl surface, but the Patagonian specimens differ by having a pleural angle of $100^{\circ}$ (versus $85^{\circ}$ ). G. (Stenozone) argentinum Reed (Sabattini and Noirat, 1969), from the Tepuel-Genoa and Calingasta-Uspallata basins, shows a similar nodose spiral pattern on the upper whorl face, but it is distinguished by having a pleural angle of $100^{\circ}$ (versus $120^{\circ}$ ), and only growth lines on the outer whorl surface.

This material may represent a new species; however, because it consists only of fragmentary external molds, it is provisionally left in open nomenclature.

Genus Ananias Knight, 1945

Type species: Phanerotrema? welleri Newell, 1935, from the upper Pennssylvanian of USA, by original designation.

Ananias riccardii Pinilla, 2012 Figure 9, F, H, K

v.1978 Glabrocingulum (Ananias) sp. Sabattini, p. 48-49, pl. 2, fig. 15

*2012 Ananias riccardii Pinilla, p. 360-363, figs. 5 a-b, 6 a-b
Material: Twenty-three external molds in concretionary samples.

Geographic and stratigraphic provenance: MPEF-PI 6305-6307, 6310 from fossil site-1; MPEF-PI 2298, 3063, 3068, 3069, 6262 from fossil site-2; MPEF-PI 6271, 6276, 6279-6284; 6292-6296, 6300, 6322, 6327, 6329, 6334 from fossil site-3; MPEF-PI 6356-6359; 6363-6365 and 6370 from fossil site-5. All fossil-sites located upstream at right bank of Quebrada de los puestos Güera-Peña, northern Sierra de Tecka (Figs. 2, 4), Pampa de Tepuel Formation, Languigneotus laevicaudatum Subzone (late Pennsylvanian).

Description: The specimens studied have faint spiral lirae on the selenizone. In addition, external molds of the last whorl show a well-developed turbinate shell. The upper whorl surface is inclined and flat, with 17-20 faint nodose spiral lirae by intersection with growth lines. The pleural angle ranges from $83^{\circ}$ to $89^{\circ}$. The outer whorl profile is convex and exhibits delicate spiral lirae and growth lines. The selenizone is narrow, $0.6-1 \mathrm{~mm}$ in width, slightly concave, with faint lunulae and 5 spiral lirae. The base is convex, rounded and phaneronphalous, with numerous closely spaced nodose spiral elements.

Discussion: The presence of faint spiral lirae on the selenizone is a distinctive feature of Ananias. Following the diagnosis of Pinilla (2012), the material is assigned to $A$. riccardii, which was originally described from the classic locality of Cerro Mina (Sierra de Languiñeo, Tepuel-Genoa Basin).

Ananias riccardii is closely similar to the type species, A. welleri Newell, 1935, from the Moskovian of USA (Newell, 1935; Hoare, 1961), in having a similar pleural angle $\left(85^{\circ}\right.$ versus $\left.83^{\circ}\right), 10-14$ spiral lirae on the upper whorl surface (versus 17-20), and a convex, phaneronphalous base. However, the North American species differs by having a vertical outer whorl face.

\section{Subfamily Neilsoniinae Knight, 1956 \\ Genus Peruvispira Chronic, 1949}

Type species: Peruvispira delicata Chronic, 1949, from the upper Pennsylvanian-lower Permian of Peru, by original designation.

\section{Peruvispira teckaensis sp. nov. Figure 9, M-P}

Material: Two external molds preserved in concretionary samples. 
Etymology: Refers to the Sierra de Tecka, Chubut Province, Argentina.

Holotype: MPEF-PI 6275

Paratype: MPEF-PI 6285

Geographic and stratigraphic provenance: MPEFPI 6275 and 6285 from fossil site-3. Fossil-site located upstream at right bank of Quebrada de los puestos Güera-Peña, northern Sierra de Tecka (Figs. 2, 4), Pampa de Tepuel Formation, Languigneotus laevicaudatum Subzone (late Pennsylvanian).

Diagnosis: Shell small, turbiniform, with four whorls; pleural angle of $58^{\circ}$; upper whorl surface straight; outer whorl surface slightly concave, with a narrow selenizone bounded by two spiral cords; alveozone concave above a peripheric peribasal carina; ornamentation consisting of collabral lirae; base convex, anonphalous.

Description: Shell small and gradate, with four whorls and a height of $5.5 \mathrm{~mm}$. Pleural angle of $58^{\circ}$. Upper whorl surface inclined and flattened. Ornamentation consisting of closely spaced ( 8 per $\mathrm{mm}$ ) collabral threads. The outer whorl surface bears a concave selenizone (width $=0.4 \mathrm{~mm}$ ) which is bounded by two spiral cords that occupy about one-third of the surface. Below the selenizone, a concave alveozone precedes a faint peribasal carina. This carina limits the base of the shell, which is convex and anonphalous. Discussion: Peruvispira teckaensis sp. nov. mostly resembles the type species, $P$. delicata Chronic, 1949, from the Bashkirian-Moskovian of the Parana Basin, Brasil (Rocha Campos, 1966), in having a similar pleural angle $\left(56^{\circ}\right.$ versus $\left.58^{\circ}\right)$ and ornamention pattern (collabral lirae 7 per mm versus 8 ), but differs by showing a broad selenizone with well-marked lunulae, and a slightly convex upper whorl surface. Peruvispira sueroi Sabattini and Noirat (1969), from the Bashkirian-Artinskian of the Tepuel-Genoa Basin, has similar dimensions ( $5 \mathrm{~mm}$ in height) and collabral threads ( 8 per $\mathrm{mm}$ ), but differs by having a higher pleural angle $\left(70^{\circ}-76^{\circ}\right.$ versus $\left.58^{\circ}\right)$.

Peruvispira canningensis Taboada et al., 2015, from the Sakmarian of the Canning Basin, Western Australia, possesses a similar number of collabral elements (10 versus 8 ), but differs from Peruvispira teckaensis sp. nov. by having a pleural angle of $40^{\circ}$ (versus $58^{\circ}$ ). Peruvispira kuttungensis Campbell, 1961, from the Bashkirian-Moskovian of New South Wales, is distinguished by having a flat to convex upper whorl surface, and a rounded to convex outer surface.
Class Bivalvia Linnaeus, 1758

Clade Eubivalvia Carter et al., 2011

Subclass Protobranchia Pelseneer, 1889

Superorder Nuculiformii Dall, 1889

Order Nuculida Dall, 1889

Superfamily Nuculoidea Gray, 1854

Family Nucuculidae Gray, 1854

Subfamily Nuculinae Gray, 1854

Genus Nuculopsis Girty, 1911

Type species: Nucula ventricosa Hall, 1858

from the Upper Carboniferous of Iowa, USA, by original designation.

Subgenus Nuculopsis (Nuculopsis) Dickins, 1963

Nuculopsis (Nuculopsis) patagoniensis

González, 1969

Figure 10, A-D

v*1969 Nuculopsis (Nuculopsis) patagoniensis nov. sp., González, pp. 237-238, pl. I, figs. 1-5.

1979 Nuculopsis (Nuculopsis) patagoniensis González, Amos, p. 104 (copy González, 1969, Fig. 5)

Material: Nineteen internal and external molds. Geographic and stratigraphic provenance: MPEF-PI 6330, 6331, 6335, 6336 from fossil site-1; MPEF-PI6247-6249, 6251, 6332 from fossil site-2; MPEF-PI 6183-6186, 6188, 6189, 6200 and 6318 from fossil site-3. All fossil-sites located upstream at right bank of Quebrada de los puestos GüeraPeña, northern Sierra de Tecka (Figs. 2, 4), Pampa de Tepuel Formation, Languigneotus laevicaudatum Subzone (late Pennsylvanian).

Description: Nuculiform, medium- to large-sized suboval shell, inequilateral slightly extended toward anteroventral margin, valves inflated, longer than high. Umbos incurved above dorsal margin toward the back of the shell, opisthogyrate, placed posteriorly to mid-length, at about $1 / 3$ of total length from posterior end. Margins are convex and continuous, without angles. No distinct lunule or escutcheon. Hinge gradidentate with convexodont teeth. Anterior part of hinge longer than posterior part, with chevronshaped teeth and sockets decreasing in size toward umbo. Posterior teeth also decreasing in size toward umbo. Anterior and posterior teeth narrow, tall and triangular. Muscle scars weakly impressed. External 


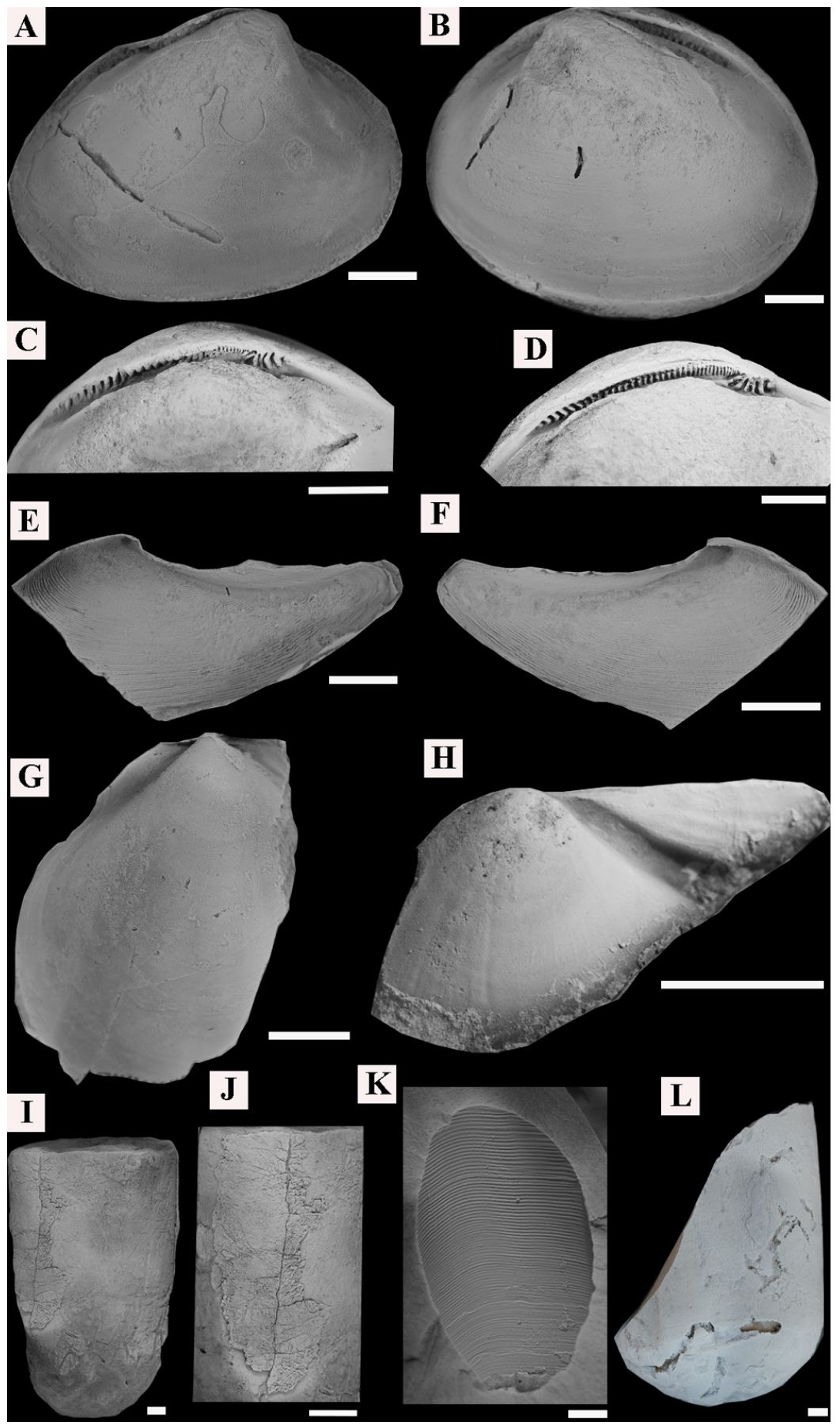

FIG 10. A-D. Nuculopsis (Nuculopsis) patagoniensis González, 1969; A. Left valve internal mold in lateral view, MPEF-PI 6189; B. Right valve internal mold in lateral view, MPEF-PI 6335; C-D. Detail of dentition; C. MPEF-PI 6186; D. MPEF-PI 6185; E-F. Phestia tepuelensis González, 1969; E. Right valve external mold in lateral view, MPEF-PI 6187b; F. Left valve external mold in lateral view, MPEF-PI 6187a; G. Streblopteria sp., right valve internal mold in lateral view, MPEF-PI 6255; H. Streblochondria sueroi González, 1969 right valve internal mold in lateral view, MPEF-PI 6218; I-J. Sueroceras? sp. MPEF-PI 6354; K. Mitorthoceras? sp., external mold, MPEF-PI 6355b. L. Pseudortoceratidae gen. et sp. indet, internal mold, MPEF-PI 6353. Scale bar: $5 \mathrm{~mm}$. 
surface ornamented with regular concentric ridges. Inner margin smooth.

Discussion: N. (Nuculopsis) darlingensis Dickins, 1963, from the Lower Permian of Western Australia, is closely related to $N$. (Nuculopsis) patagoniensis González, but the Australian species differs by having a more conspicuous umbo in a less posterior position. Pagani (2004) described two other species of Nuculopsis (Nuculopsis) from the CarboniferousPermian of Patagonia. Nuculopsis (N.) teckaensis Pagani is suboval to subtriangular in outline, has a medially positioned umbo, and exhibits teeth of different shape and size; whereas Nuculopsis (Nuculopsis) sp. has a truncate posterior margin, the umbo is in a medial position, and the anterior faces of the teeth are weakly striate.

\section{Superorder Nuculaniformii Carter, Campbell and Campbell, 2000 \\ Order Nuculanida Carter, Campbell and Campbell, 2000}

Superfamily Nuculanoidea Adams and Adams, 1858

Family Polidevciidae Kumpera,et al., 1960

Genus Phestia Chernyshev, 1951

Type species: Leda inflatiformis Chernyshev, 1939 from the Carboniferous of Russia, by original designation.

Phestia tepuelensis González, 1969 Figure 10, E-F

v*1969 Phestia tepuelensis González, pp. 239243, pl. I, figs. 6-9.

v1977 Phestia tepuelensis González, González, p. 114, pl. 1, fig. 8.

1979 Phestia tepuelensis González, Amos, p. 106 (copy González, 1969, pl. I, fig. 6)

v1987 Phestia sp., Cúneo and Sabattini, p. 293, pl. I, fig. 18.

2002 Phestia tepuelensis González, Pagani, p.

37-43, pl. 5, figs. a-k, pl. 6, figs. a-j.

2004 Phestia tepuelensis González, Pagani, p. 276-280, pl. 7, figs. A-L.

2010 Waterhouseus tepuelensis (González, 1969); González, p. 67-69, pl. 5, figs. A-B.

Material: One external mold of both valves and one fragmentary external mold.

Geographic and stratigraphic provenance: MPEFPI 6314; 6187 from fossil site-3. Fossil site located upstream at right bank of Quebrada de los puestos Güera-Peña, northern Sierra de Tecka (Figs. 2, 4), Pampa de Tepuel Formation, Languigneotus laevicaudatum Subzone (late Pennsylvanian).

Description: Shell inequilateral, with a long posterior rostrum. Anterior, antero-ventral and postero-ventral margins regularly rounded. Umbo placed anteriorly, opisthogyrous, moderately projected dorsally. Shell densely covered with thin comarginal ribs and finer radial riblets, which conform a cancellate ornamentation. With small nodules at intersection of comarginal and radial ribs.

Discussion: The ornament pattern of the studied material is diagnostic of Phestia tepuelensis González, 1969. González (2010) proposed the new genus Waterhouseus to include this species, but the diagnosis of Waterhouseus is not accurate and the differences with Phestia and other close taxa such as Polidevcia are not properly discussed. Thus we provisionally keep the original generic name for the Patagonian species. A revision of these genera is necessary, but it exceeds the scope of this paper and will be the subject of future research.

Subclass Autobranchia Grobben, 1894

Superorder Pteriomorphia Beurlen, 1944 Order Pectinida Gray, 1854

Superfamily Chaenocardioidea Miller, 1889

Family Streblochondriidae Newell, 1938

Subfamily Streblochondriinae Newell, 1938

Genus Streblochondria Newell, 1938

Type species: Aviculopecten sculptilis Miller,

1891 from the Upper Carboniferous of

Missouri, USA, by original designation.

Streblochondria sueroi González, 1969, Figure 10, $\mathrm{H}$

v*1969 Streblochondria sueroi González, p. 245-246, pl. I, figs. 10-15.

1979 Streblochondria sueroi González, Amos, p.

108 (copy González, 1969, pl. I, Fig. 15). v2002 Streblochondria sueroi González, Pagani, pp. 123-127, pl. 17, figs. a-k.

v2005 Streblochondria sueroi González, Pagani, pp. 591-593, pl. 5, figs. A-H.

Material: Three external molds.

Geographic and stratigraphic provenance: MPEFPI 2300 from fossil site-2; MPEF-PI 6218 and 6328 from fossil site-3. All fossil sites located upstream at 
right bank of Quebrada de los puestos Güera-Peña, northern Sierra de Tecka (Figs. 2, 4), Pampa de Tepuel Formation, Languigneotus laevicaudatum Subzone (late Pennsylvanian).

Description: Right valve with cardinal line shorter than total shell width. Anterior auricle long, rounded, trigonal, with a marked bysal sinus. Posterior auricle small, triangular. Umbo orthogyrous. Apical angle of $90^{\circ}$. Shell ornamented with wavy radial ribs crossed by regular concentric ribs to produce a cancellate pattern, with small nodes at intersection points.

Remarks: This species has previously been reported from many Carboniferous-Permian localities of the Tepuel-Genoa Basin. Streblochondria sueroi closely resembles Streblochondria sculptilis (Miller), from the Upper Paleozoic of USA (Newell and Boyd, 1995), but the latter shows stronger nodes or scales at the intersections of the concentric and radial ribs. For a complete comparison see Pagani (2005).

\section{Subfamily Streblopteriinae Waterhouse, 2008 Genus Streblopteria McCoy, 1851 \\ Type species: Meleagrina laevigata McCoy, 1844 from Carboniferous of Ireland, by subsequent designation of Meek and Worthen, 1866.}

\section{Streblopteria sp. \\ Figure 10, G}

Material: One external mold and three internal molds, left valves.

Geographic and stratigraphic provenance: MPEFPI 6220, 6253, 6255 from fossil site-2. Fossil site located upstream at right bank of Quebrada de los puestos Güera-Peña, northern Sierra de Tecka (Figs. 2, 4), Pampa de Tepuel Formation, Languigneotus laevicaudatum Subzone (late Pennsylvanian).

Description: Shell orbicular, acline. Anterior, ventral and posterior margins of disc regularly rounded. Cardinal margin straight, shorter than maximun width of shell. Umbo orthocline. Beak slightly projected above hinge margin. Anterior auricle slightly larger than posterior one. Left anterior auricle flat and subquadrate; posterior auricle triangular. Ligament area triangular, elongate, without a distinct chondrophore. External surface with inconspicuous comarginal growth-lines.

Remarks: Streblopteria sp. closely resembles Streblopteria lagunensis Pagani, 2006, from other localities of the Tepuel-Genoa Basin. However, because the specimens from Güera-Peña are fragmentary, they are provisionally left under open nomenclature.

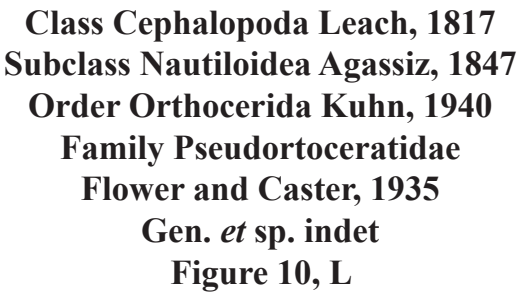

Material: One fragmentary internal mold. Geographic and stratigraphic provenance: MPEF-PI 6353 from fossil site 3, located upstream at right bank of Quebrada de los puestos GüeraPeña, northern Sierra de Tecka (Figs. 2, 4), Pampa de Tepuel Formation, Languigneotus laevicaudatum Subzone (late Pennsylvanian).

Description: Phragmacone orthoconic, $47.8 \mathrm{~mm}$ long; cross section subcircular, $29.6 \mathrm{~mm}$ in diameter. Sutures straight. Siphuncule with a central position and a diameter of $4.3 \mathrm{~mm}$.

Genus Sueroceras Riccardi and Sabattini, 1975 Type species: Sueroceras irregulare Riccardi and Sabattini, 1975, p. 124; original designation.

\section{Sueroceras? sp. \\ Figure 10, I-J}

Material: One fragmentary internal mold and shell preserved.

Geographic and stratigraphic provenance: MPEFPI 6354, 6368 from fossil site-5. Located upstream at right bank of Quebrada de los puestos Güera-Peña, northern Sierra de Tecka (Figs. 2, 4), Pampa de Tepuel Formation, Languigneotus laevicaudatum Subzone (late Pennsylvanian).

Description: Phragmacone orthoconic, $84.7 \mathrm{~mm}$ long; cross section subcircular, with a diameter of $51.1 \mathrm{~mm}$. Sutures straight. Exoskeletal surface ornamented with transverse and longitudinal lirae forming a reticulate pattern.

Genus Mitorthoceras Gordon, 1960

Type specie: Mitorthoceras perfilosum Gordon, 1960 by original designation.

Mitorthoceras? sp.

Figure 10, K 
Material: Two fragmentary external molds. Geographic and stratigraphic provenance: MPEF-PI3065 from fossil site-2; MPEF-PI 6355 from fossil site-4. All fossil site located upstream at right bank of Quebrada de los puestos Güera-Peña, northern Sierra de Tecka (Figs. 2, 4), Pampa de Tepuel Formation, Languigneotus laevicaudatum Subzone (late Pennsylvanian).

Description: Phragmacone orthoconic, $51 \mathrm{~mm}$ long; cross section circular, with a diameter of $51.1 \mathrm{~m}$. Exoskeletal surface ornamented with fine, transverse ribs averaging 3 per $\mathrm{mm}$.

\section{Phylum Cnidaria Hatschek, 1888 \\ Subphylum Medusozoa Petersen, 1979 \\ Class Scyphozoa Götte, 1887 \\ Subclass Conulata Moore and Harrington 1956 \\ Order Conulariida Miller and Gurley, 1896 \\ Family Conulariidae Walcott, 1886 \\ Genus Paraconularia Sinclair, 1940 \\ Type species. Conularia inaequicostata \\ Koninck, 1883, from the Tournaisian of \\ Belgium, by original designation.}

Discussion: Paraconularia Sinclair, 1940 hardly differs from Calloconularia Sinclair, 1952 because the latter has a smaller-sized shell, crowding transverse ribs and well-marked longitudinal bars in the interspaces (Campbell, 1962); characters that may lack generic significance (Leme, 2006; Leme et al., 2008; this paper). Adesmoconularia Driscoll, 1963 was also regarded as a junior synonym of Paraconularia by Babcock and Feldman (1986a, b), although this affirmation was questioned by Sendino (2007).

In Patagonia, five species of conulariids were described by Mariñelarena (1970) and Cúneo and Sabbattini (1987) mainly on the basis of biometric characters. However, because some of these features could be of taphonomic origin (Feldman and Babcock, 1986; Simöes et al., 2003), a comprehensive systematic revision is necessary and will be the subject of a future paper.

\footnotetext{
Paraconularia cf. P. ugartei Cúneo and Sabattini, 1987

Figure 11, A-I

*1987 Paraconularia ugartei Cúneo and Sabattini, pp. 289-290, pl. I, figs. 1-3. p.2004 Paraconularia ugartei Cúneo and Sabattini; Sabattini and Hlevszevitsch, pp. 400-401, figs. 1, A-F; figs. 2, A-E.
}

Material: Fifty-one external molds and six internal molds.

Geographic and stratigraphic provenance: MPEF-PI 3066, 3070-3072, 3281, 6190- 6193, 6195, 6215,6216 from fossil-site 2; MPEF-PI 6196, 6197 , 6198, 6201-6214, 6217; 6222-6246 from fossil-site 3; MPEF-PI 6337-6339 from fossil-site 5. All fossil-sites located upstream at right bank of Quebrada de los puestos Güera-Peña, northern Sierra de Tecka (Figs. 2, 4). Pampa de Tepuel Formation, Languigneotus laevicaudatum Subzone (late Pennsylvanian).

Description: Medium size shell, straight, tapering, subquadrate in cross section, with faces that are approximately equal in width. Maximum shell length of $35 \mathrm{~mm}$ and width of $11 \mathrm{~mm}$. Apical angle between $10^{\circ}$ and $15^{\circ}$. Periderm ornamented with trochoidal transverse ribs which are straight adapically to slightly curved adaperturally, in a number of $2-3 / \mathrm{mm}$. In the mid facial line, ribs are alternate, opposite or continuous, always inflected adaperturally. Ribs exhibit numerous subcircular tubercles, $4-6 / \mathrm{mm}$ in average, reaching up to $9 /$ $\mathrm{mm}$ toward the adapical region in some specimens. Tubercles, as well as ribs, are more numerous toward the adapical region of the shell. Corner grooves transversely angulate, with the ends of the ribs from one face alternating with the ends of the ribs from the other face and showing an adapertural flexion. Interspaces concave, two or three times wider than ribs, usually smooth, although oblique bars close to the facial edges or the facial mid lines are present in some specimens. Facial mid-lines defined by an inflection, interruption and/or alternation of the ribs. Ridge articulation (= connection of Sendino, 2007) of both gothic arch style and inflected gothic style, can be present in the same specimen. Some specimens exhibit an internal septum on the inner side of the mid-line region.

Discussion: The specimens studied resemble $P$. ugartei Cúneo and Sabattini (1987) by sharing a similar number of ribs and tubercles per millimeter, although the latter shows a wider apical angle $\left(14^{\circ}\right.$ $22^{\circ}$ ). Paraconularia pulcheria Mariñelarena, 1970 has a similar size and a similar number of transverse ribs, but the ridges are sinuous adapically, the corner grooves are rounded and the apical angle is wider $\left(22^{\circ}\right)$. P. acuminata Mariñelarena, 1970 exhibits a similar ornamentation and a narrow apical angle $\left(15^{\circ}\right)$; nevertheless, its shell is bigger than that of $P$. cf. ugartei, and has an adapertural furrow on the mid-facial line. 

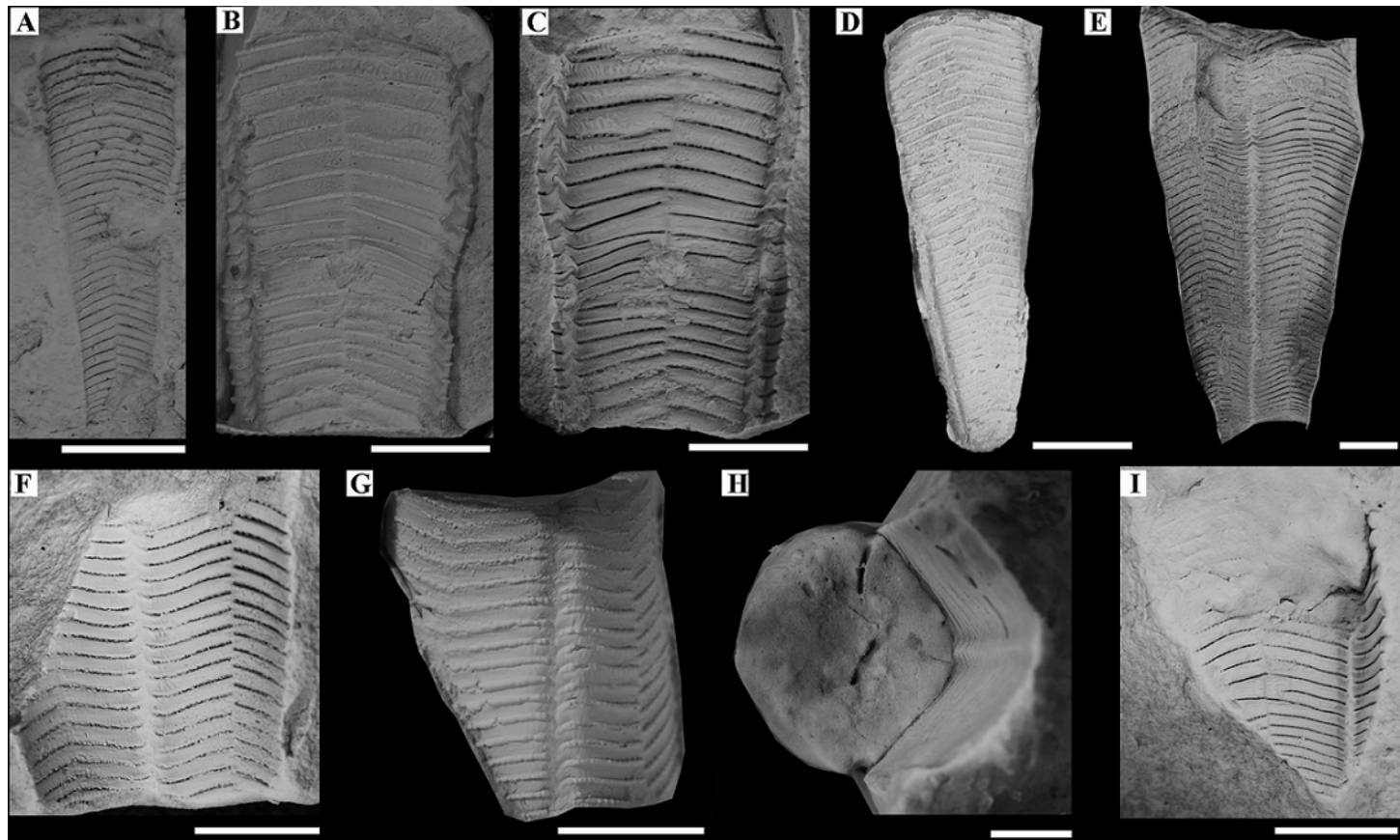

G
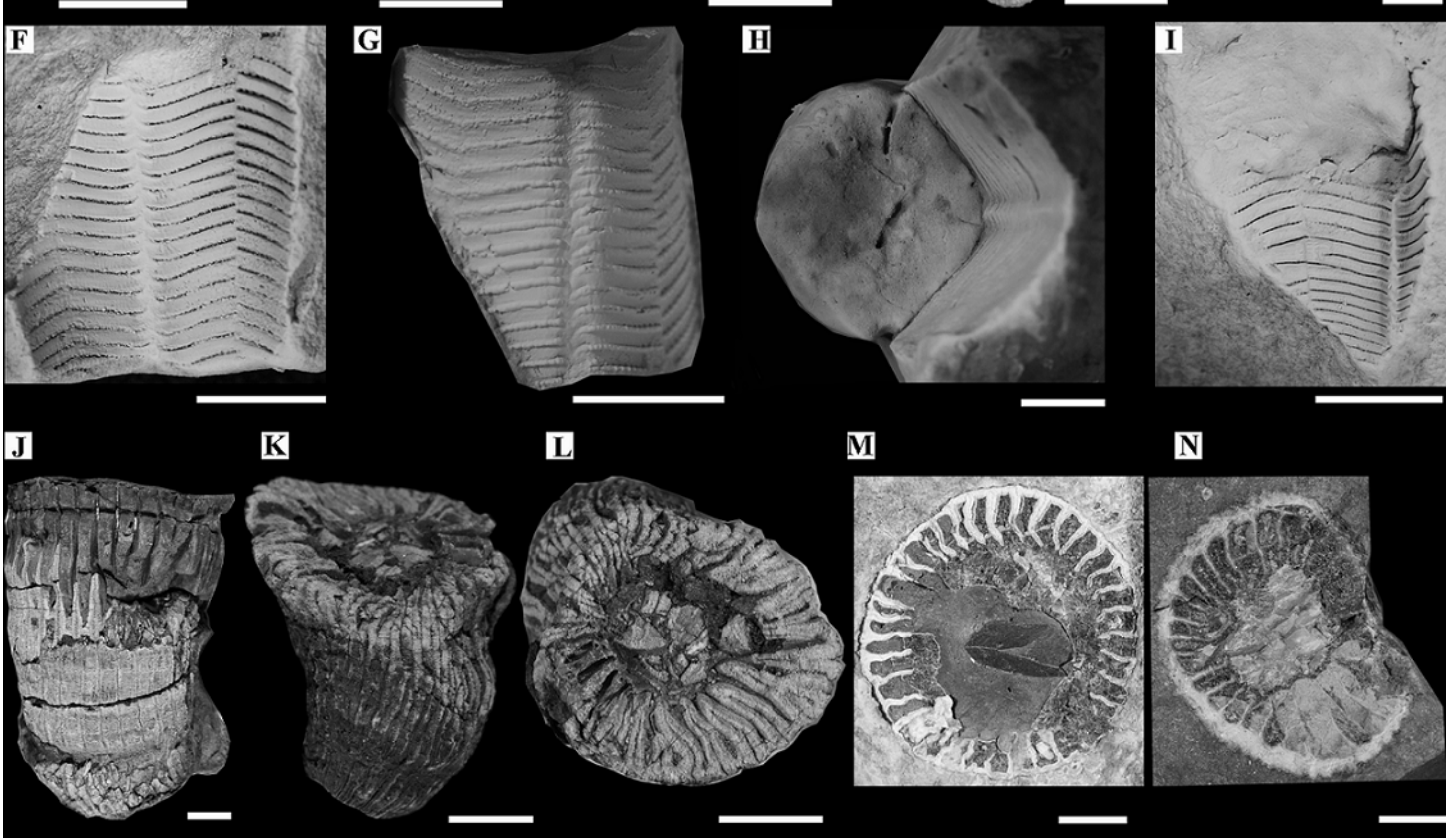

$\mathbf{L}$

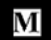

$\mathbf{N}$
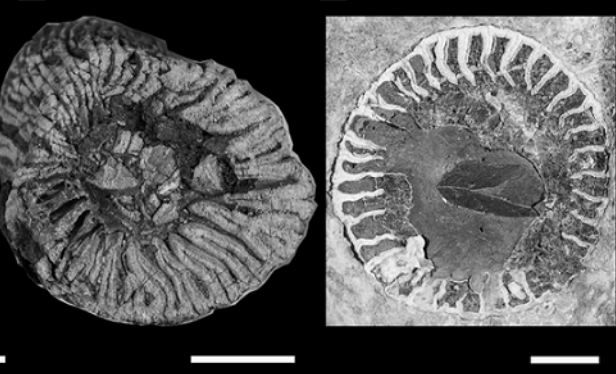

FIG 11. A-I. Paraconularia cf. P. ugartei Cúneo and Sabattini, 1987; A. Lateral view, MPEF-PI 6195; B-C. MPEF-PI 6190; B. Polyvinilxyloxane cast external view; C. External mold in lateral view; D. External lateral view, MPEF-PI 6197; E. External mold frontal view, MPEF-PI 6209; F-G. Frontal view, MPEF-PI 6198; F. External mold; G. Polyvinilxyloxane cast; H. External and internal mold showing the cross section, MPEF-PI 6223; I. Fragmentary external mold, MPEF-PI 6201; J-N. ?Family Lophophyllidiidae Moore and Jeffords, 1945; J-L. MPEF-PI 6343; J. Lateral view; K. Lateral view apical fragment; L. Transverse view apical fragment; M. Transverse section, MPEF-PI 6345; N. Transverse section, MPEF-PI 6342. Scale bar: $5 \mathrm{~mm}$.

Paraconularia tuberculata (Fletcher, 1938) (see also Campbell, 1962), from the middle Carboniferous of New South Wales, Australia, differs from $P$. cf. $P$. ugartei by having sinuous ribs, conspicuous longitudinal grooves, and a rectangular cross section. Paraconularia nefarious Campbell, 1962, from the Pennsylvanian of Australia, is distinguished because it has interspaces ornamented with longitudinal bars which correspond exactly in position with the rows of pustules. P. cf. P. ugartei and Calloconularia minima Campbell, 1961, from the Booral Formation (Pennsylvanian) of Australia, have similar ridge articulations and numbers of ribs per millimeter, but the latter exhibits a wider apical angle $\left(20^{\circ}-26^{\circ}\right)$ and a distinct longitudinal ridge across the midline of each face. 
Subphylum Anthozoaria Petersen, 1979

Class Anthozoa Ehrenberg, 1831

Subclass Rugosa Milne-Edwards and Haime, 1850

Order Stauriida Verrill, 1865

\section{?Family Lophophyllidiidae Moore and Jeffords, 1945 \\ Figure 11, J-N}

Material: Six specimens preserved as internal molds and transverse sections.

Geographic and stratigraphic provenance: MPEFPI 6345 from fossil-site 4; MPEF-PI 6341-6344 from fossil-site 5. All fossil-sites located upstream at right bank of Quebrada de los puestos GüeraPeña, northern Sierra de Tecka (Figs. 2, 4). Pampa de Tepuel Formation, Languigneotus laevicaudatum Subzone (late Pennsylvanian).

Discussion: The specimens are fragmented and poorly preserved. They consist of solitary medium-sized, curved corals of conical to conical-cylindrical shape. In transverse section, the corallia are circular and the wall is proportionately thin. Septa are arranged radially; tabulae and dissepimentarium are not observed. The external surface of the wall is marked by wrinkles and fine growth lines, with longitudinal furrows matching the internal septa.

\section{Phylum Arthropoda \\ Class Trilobita Walch, 1771}

Order Proetida Fortey and Owens, 1975

Family Brachymetopidae Prantl and Přibyl, 1950

Genus Australosutura Campbell and Goldring in Amos et al., 1960

Type species: Cordania gardneri Mitchell, 1922, from the Upper Carboniferous of Australia, by original designation.

Australosutura argentinensis Hahn and Hahn, 1969

Figure 12, A-P

v1960 Australosutura gardneri (Mitchell), Amos, Campbell and Goldring, p. 231-234, Pl. 39, Figs. 1-11 (only)

1960 Australosutura gardneri (Mitchell), Amos, p. 99 1964 Australosutura gardneri (Mitchell), Amos, p. 62 1969 Australosutura argentinensis Hahn and Hahn, p. 14-15
1973 Australosutura gardneri (Mitchell), Amos et al., p. 7

1978 Australosutura gardneri (Mitchell), Polanski, pl. 2, Fig. 1

1980 Australosutura gardneri (Mitchell), Archangelsky et al., p. 267

1986 Australosutura gardneri (Mitchell), Andreis et al., p. 176, 177

1997 Australosutura argentinensis Hahn and

Hahn, Simanauskas and Sabattini, p. 54

Material: Five cephala, two pygidia and two exoskeletal fragments.

Geographic and stratigraphic provenance: FML 4007a-b, 4008; MPEF-PI 3073, 6375 from fossil site-2; MPEF-PI 6373, 6374 from fossil site-3. All fossil-sites located upstream at right bank of Quebrada de los puestos Güera-Peña, northern Sierra de Tecka (Figs. 2, 4), Pampa de Tepuel Formation, Languigneotus laevicaudatum Subzone (late Pennsylvanian).

Description: Exoskeletal surface with numerous tubercles of different sizes. Cephalon semicircular in outline, strongly convex. Anterior margin of cranidium well rounded; glabella large, strongly inflated, surrounded by well defined axial furrows, subparallel-sided to subconical in outline and broadly rounded anteriorly, occupying $74-78 \%$ of the total cranidial length; with one to two pairs of glabellar furrows, of which the S1 is deepest and isolating subtriangular L1; occipital furrow straight to slightly bowed backwards, marked throughout, delimiting a short (sag.) and convex occipital ring. Preglabellar field very short (sag.); cephalic border furrow broad and concave; anterior border convex; anterior branches of facial sutures divergent forward; palpebral lobe prominent, elevated above surface of fixed cheek, situated close to the glabella and opposite $\mathrm{S} 1$; posterior branches oblique backwards; free cheek with a moderately long genal spine; cephalic doublure carrying 10-12 terrace lines. Pygidium semielliptical in outline, strongly convex; pygidial axis well defined, inflated, very long, tapered backwards, with 15 rings and a terminal piece; pleural fields large, with conspicuous pleural furrows and longitudinally arranged rows of tubercles of variable size.

Discussion: Suero (1948, 1953, 1958,1961) first cited the occurrence of trilobites in the upper Paleozoic of the Tepuel-Genoa Basin and pointed out its biostratigraphic value. The trilobites collected by Suero were described in great detail by Amos et al. (1960) 

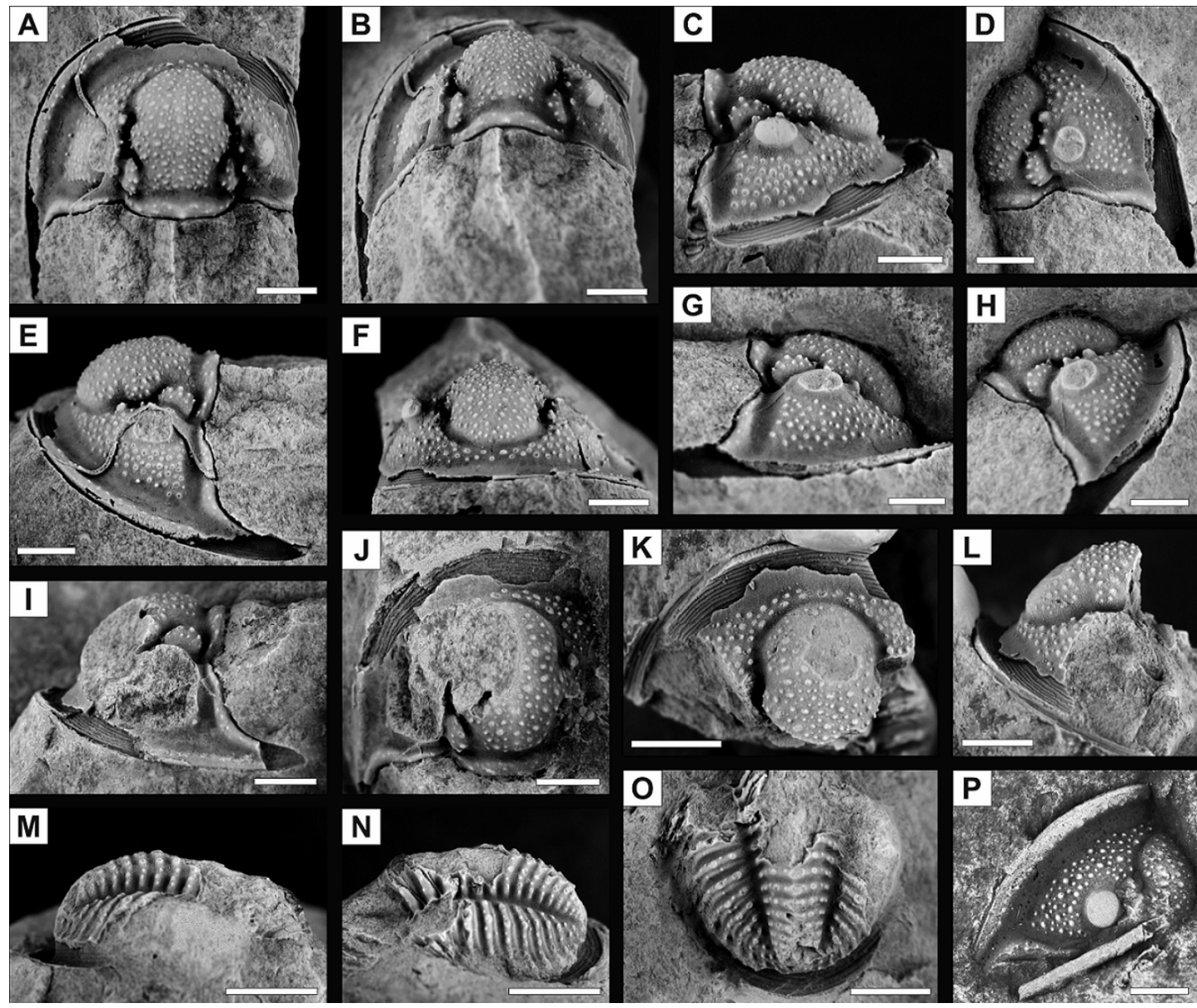

FIG. 12. A-P. Australosutura argentinensis Hahn and Hahn, 1969; A-C, E-F. Cephalon in dorsal, postero-dorsal, lateral and anterior views, FML 4007A; D, G-H. Cephalon in dorsal, lateral and oblique views, FML 4008; I-J. Cephalon in lateral and dorsal views, MEF6375; K-L. Fragmentary cephalon in dorsal and lateral views, MPEF-PI 6373a; M-O. Pygidium in lateral and dorsal views, MEF 6373; P. Cephalon in dorsal view, latex mold, MPEF-PId 6373b. Scale bar: 3 mm.

and assigned to Australosutura gardneri (Mitchell, 1922); a brachymetopid previously reported from the Westphalian (middle Pennsylvanian) of eastern Australia (Mitchell, 1922, 1924; Amos et al., 1960). However, the presence of slight differences between the morphology of the Australian and the Argentinean specimens (see Amos et al., 1960; Campbell and Engel, 1963; Ormiston, 1966) led Hahn and Hahn (1969) to erect the new species $A$. argentinensis. The latter differs from A. gardneri mainly in having a more inflated glabella, distinctive tubercules on the cephalic borders and the occipital ring, and a strongly arched pygidium with pleural fields that occupy, in side view, more than half of the total pygidial height (cf. Amos et al., 1960; Hahn and Hahn, 1969). Australosutura argentinensis is a rare member of the cold-water Lanipustula and Languigneotus faunas, which characterize the upper part of the Pampa de Tepuel Formation (e.g., Amos, 1960, 1964; Amos et al., 1973; Archangelsky et al., 1980; Andreis et al., 1986; Simanauskas and Sabattini, 1997; Pagani and Taboada, 2011; Taboada and Shi, 2011).

Trilobites from Sierra de Tecka are reported herein for the first time. The specimens studied represent an Australosutura species with coarse, widely-distributed tubercules on the exoskeleton, a subcylindrical, very inflated glabella, a short preglabellar field, an elongate (sag.), strongly arched pygidium, and large 
pleural fields, so they are confidently assigned to A. argentinensis Hahn and Hahn. The fixed-cheeks exhibit a pair of conspicuous tubercles opposite S2 (e.g., Fig. 12A, E), and the cephalic border furrow is either smooth (Fig. 12A, B, D, E, H, K) or pitted (Fig. 12P). In order to complement the systematic descriptions furnished by Amos et al. (1960) and Hahn and Hahn (1969), updated comparisons of $A$. argentinensis with other species of Australosutura are provided below.

Australosutura georgiana Rich, from the Osagean of the Appalachians, USA (Rich, 1966; Brezinski, 2009), differs from A. argentinensis mainly by having a longer (sag.) preglabellar field. Australosutura strattonporterae (Rowley), from the Louisiana Limestone (lowest Carboniferous) of Missouri, USA (Rowley, 1908; Williams, 1943; Hahn and Hahn, 1969) has, in addition, a shorter and somewhat conical glabella, with a more expanded (tr.) glabellar lobe L1. Similarly, Australosutura lodiensis (Meek, 1875), from the Lower Mississippean of western USA (Brezinski, 2009), is distinguished from $A$. argentinensis by its forward tapering glabella.

Australosutura argentinensis and A. llanoensis Brezinski, from the Tournaisian of the southern United States (Brezinski, 1998), share a cranidium with a cylindrical glabella. However, the glabella of A. llanoensis is less inflated, whereas the pygidium is clearly distinguished from that of $A$.argentinensis by its low profile and its less prominent tubercles (Brezinski, 1998). Australosutura asiatica Yuan and Xiang, from the lowest Carboniferous of China (Yuan and Xiang, 1998), differs by having coarser tubercles on the librigenae.

Australosutura campbelli Engel and Morris, from the Lower Carboniferous of eastern Australia (Engel and Morris, 1992), is distinguished from A. argentinensis by having more delicate nodes on the cephalon, a less convex glabella, a much longer (sag.) frontal area, and a much shorter (sag.) cephalic border furrow. Australosutura aff. A. gardneri, from the Mississippian (Viséan) of Oklahoma, USA (Ormiston, 1966), differs by its less inflated cephalon and its longer (sag.) preglabellar field (cf. Ormiston, 1966). As stated by Campbell and Engel (1963), Australosutura sp. from the Viséan of New South Wales, Australia (Campbell and Engel, 1963), differs from A. argentinensis mainly by the relatively greater width/length ratio of the pygidium.
Australosutura osagensis Brezinski, from the Mississippian (Osagean) of Missouri and New Mexico, USA, was described only on the basis of pygidia (Brezinski, 2000, 2007). It differs from $A$. argentinensis by having a wider (tr.) axis, as well as a smaller number of axial rings. Australosutura elegans (Girty), from the Lower Mississippian of Arkansas, USA (Girty, 1915), is easily differentiated by its strongly tapered posterior pygidial axis, its straight pleural furrows, and its distinctive postaxial region.

\section{Acknowledgments}

We thank Dr. C.R. González, Dr. G.A. Cisterna and an anonymous reviewer, as well as the Andean Geology editor Dr. W. Vivallo, for their helpful comments and thorough review of the manuscript. L. Reiner, L.Canessa and E. Ruigomez provided technical assistance. Lic. A. Robles Vilches and Lic. C. Pardo are thanked for their help during field work. We also want to thank Dr. A. Riccardi for making collections of the División Paleozoología Invertebrados (Museo de La Plata) available for study. M. Campaña produced figure 4. This research was supported by the CONICET and ANPCyT (Argentina) with Projects PICT 20111589 and PICT 2013-0584. CIEMEP (Esquel), MEF (Trelew) and UNLP (La Plata) supplied laboratory facilities.

\section{References}

Adams, H.; Adams, A. 1858. The Genera of Recent Mollusca, arranged according to their organization. Van Voorst, volumes 1: 484 p., 2, 661 p., 3, 136 p. London.

Agassiz, L. 1847. An Introduction to the Study of Natural History, in a Series of lectures delivered in the Hall of the College of Physicians and Surgeons. Greeley and McElrath: 58 p. New York.

Alberti, R. 1988. Geología de la Quebrada de Güera-Peña, zona norte del borde oriental de la sierra de Tecka, Departamento de Languiñeo, Provincia del Chubut. Trabajo Final de Licenciatura (Unpublished), Facultad de Ciencias Exactas y Naturales, Universidad de Buenos Aires: $73 \mathrm{p}$.

Amos, A.J. 1958. Algunos Spiriferacea y Terebratulacea (Brach.) del Carbonífero Superior del Sistema del Tepuel (Provincia de Chubut). Contribuciones Científicas Facultad de Ciencias Exactas y Naturales, Universidad de Buenos Aires, Serie Geología 2 (3): 95-108.

Amos, A.J. 1960. Algunos Chonetacea y Productacea del Carbonífero Inferior y Superior del Sistema de 
Tepuel, Provincia de Chubut. Revista de la Asociación Geológica Argentina 15: 81-107.

Amos, A.J. 1964. A review of the marine Carboniferous stratigraphy of Argentina. In International Geological Congress, Report of the Twenty-Second Session, India, Proceedings of Gondwanas, Section 9: 53-72. New Delhi.

Amos, A.J. 1979. Faunas Carbónicas y Pérmicas. Guía Paleontológica Argentina. Parte I: Paleozoico. Publicación del Conicet: 1-154. Buenos Aires.

Amos, A.J.; Rolleri, E.O. 1965. El Carbónico marino en el Valle Calingasta-Uspallata (San Juan y Mendoza). Boletín de Informaciones Petroleras 368: 1-23.

Amos, A.J.; Campbell, K.S.W.; Goldring, R. 1960. Australosutura gen. nov. (Trilobita) from the Carboniferous of Australia and Argentina. Palaeontology 3: $227-236$

Amos, A.J.; Antelo, B.; González, C.R.; Mariñelarena, M.P.; Sabattini, N. 1973. Síntesis sobre el conocimiento bioestratigráfico del Carbónico y Pérmico de Argentina. In Congreso Geológico Argentino, No. 5, Actas 3: 3-19. Villa Carlos Paz, Córdoba.

Andreis, R.; Archangelsky, S.; González, C.; Lopez Gamundi, O.; Sabattini, N. 1986. Cuenca Tepuel Genoa. In El Sistema Carbonífero en la República Argentina (Síntesis) (Archangelsky, S.; editor). Academia Nacional de Ciencias de Córdoba: 155-182. Córdoba.

Archangelsky, S.; Azcuy, C.L.; Pinto, I.D.; González, C.R.; Marques Toigo, M.; Rösler, O.; Wagner, R.H. 1980. The Carboniferous and Early Permian of the South American Gondwana area: a summary of biostratigraphic information. In Congreso Argentino de Paleontología y Bioestratigrafía, No. 2, y Congreso Latinoamericano de Paleontología, No. 1, Actas 4: 257-269. Buenos Aires.

Babcock, L.E.; Feldman, R.M. 1986a. Devonian and Mississipian Conulariids of North America. Part A. General Description and Conularia. Annals of Carnegie Museum 55: 349-410.

Babcock, L.E.; Feldman, R.M. 1986b. Devonian and Mississipian Conulariids of North America. Part B. Paraconularia, Reticulaconularia, new genus and organisms rejected from Conulariida. Annals of Carnegie Museum 55: 411-479.

Bamber, E.W.; Waterhouse, J.B. 1971. Carboniferous and Permian Stratigraphy and Paleontology, Northern Yukon Territory, Canada. Canadian Petroleum Geology, Bulletin 19 (1): 29-250.

Batten, R.L. 1972. Permian Gastropods and Chitons from Perak, Malaysia. Part I. Chitons, Bellerophontids,
Euomphalids and Pleurotomarians. Bulletin of the American Museum of Natural History147 (1): 5-44.

Beurlen, K. 1944. Beiträge zur Stammesgeschichte der Muschelen. Sitzungsberichte der MathematischNaturwissenschaftlichen Abteilung der Bayerischen Akademie der Wissenschaften zu München: 133-145.

Borrello, A.V. 1969. Los Geosinclinales de la Argentina. Anales de la Dirección Nacional de Geología y Minería 14: 1-188.

Bouchet, P.; Rocroi, J.P. 2005. Classification and nomenclator of gastropod families. Malacologia 47: 1-397.

Bouchet, P.; Rocroi, J.P. 2010. Nomenclator of bivalve families with a classification of bivalve families by R. Bieler, J. G. Carter, and E.V. Coan. Malacologia 52 (2): 1-184.

Brezinski, D.K. 1998. Trilobites from the Lower Mississippian starved basin facies of the southern United States. Journal of Paleontology 72: 718-725.

Brezinski, D.K. 2000. Lower Mississippian trilobites from southern New Mexico. Journal of Paleontology 74: 1043-1064.

Brezinski, D.K. 2007. Lower Mississippian trilobite biostratigraphy of the Central United States, and some new Osagean species. Journal of Paleontology 81: 737-745.

Brezinski, D.K. 2009. Biostratigraphic distribution of Appalachian Carboniferous trilobites. In Carboniferous of the Appalachian and Black Warrior Basins (Greb, S.F.; Chesnut Jr., D.R.; editors). Kentucky Geological Survey, Special Publication 10, Series XII: 78-84. Kentucky.

Brunton, C.H.C. 2007. Order Productida. In Treatise on Invertebrate Paleontology, Part H, Brachiopoda, Revised 6 (Selden, P. A.; editor). Geological Society of America and the Paleontological Institute of Kansas: 2321-3226. Boulder and Lawrence.

Brunton, C.H.C.; Lazarev, S.S.; Grant, R.E.; Jin Yu-Gan. 2000. Productidina. In Treatise on Invertebrate Paleontology, Part H, Brachiopoda Revised 3 (Kaesler, L.R.; editor). Geological Society of America and the University of Kansas: 424-609. Boulder and Lawrence.

Campbell, K.S.W. 1961. Carboniferous fossils from the Kuttung Rocks of New South Wales. Palaeontology 4 (3): 428-474.

Campbell, K.S.W. 1962. Marine fossils from the Carboniferous glacial rocks of New South Wales. Journal of Paleontology 36: 38-52.

Campbell, K.S.W.; Engel, B.A. 1963. The faunas of the TournaisianTulcumba Sandstone and its members in the Werrie and Belvue Synclines, New South Wales. 
Journal of the Geological Society of Australia 10: 55-122.

Campbell, K.S.W.; McKellar, R.G. 1969. Eastern Australian Carboniferous Invertebrates: Sequence and Affinities. In Stratigraphy and Palaeontology (Campbell, K.S.W.; editor). Essays in Honour of Dorothy Hill Australian National University Press: 77-119. Canberra.

Carrizo, H.; Azcuy, C.L. 2006. Gilboaphyton argentinum sp. nov.: a herbaceous lycopod from the Early Carboniferous of Argentina. Revista Brasileira de Paleontología 9 (1): 33-40.

Carter, J.G.; Campbell, D.C.; Campbell, M.R. 2000. Cladistic perspectives on early bivalve evolution. In The evolutionary biology of the Bivalvia (Harper, E.M.; Taylor, J.D.; Crame, J.A.; editors). Geological Society Special Publication 177 (1): 47-79.

Carter, J.G.; Altaba, C.R.; Anderson, L.C.; Araujo, R.; Biakov, A.S.; Bogan, A.E.; Campbell, D.C.; Campbell, M.; Chen, J.; Cope, J.C.W.; Delvene, G.; Dijkstra, H.H.; Fang, Z.; Gardner, R.N.; Gavrilova, V.A.; Goncharova, I.A.; Harries, P.J.; Hartman, J.H.; Hautmann, M.; Hoeh, W.R.; Hylleberg, J.; Jiang, B.; Johnston, P.; Kirkendale, L.; Kleemann, K.; Koppka, J.; Křŕž, J.; Machado, D.; Malchus, N.; Márquez-Aliaga, A.; Masse, J-P.; McRoberts, C.A.; Middelfart, P.U.; Mitchell, S.; Nevesskaja, L.A.; Özer, S.; Pojeta, J. Jr.; Polubotko, I.V.; Pons, J.M.; Popov, S.; Sánchez, T.; Sartori, A.F.; Scott, R.W.; Sey, I.I.; Signorelli, J.H.; Silantiev, V.V.; Skelton, P.W.; Steuber, T.; Waterhouse, J.B.; Wingard, G.L.; Yancey, T. 2011. A Synoptical Classification of the Bivalvia (Mollusca). Paleontological Contributions 4: 1-47.

Cazau, L. 1972. Cuenca del Ñirihau-Ñorquinco-Cushamen. In Geología Regional Argentina (Leanza, A.F.; editor). Academia Nacional de Ciencias de Córdoba: $727-$ 740. Córdoba.

Chernyshev, B.I. 1939. Atlas of the guide forms of the fossil faunas of the U.R.S.S., Middle and Upper Carboniferous: Tsentra'nyy Nauchno-Issledovatel' skiy. Geologo-Rasveddochnyy Institut 5: 113-126. Leningrad and Moscow.

Chernyshev, B.I. 1951. The family Ledidae in the Carboniferous deposits of U.R.S.S. Trudy Institut Geologicheskikh Nauk, Seriya Stratigrafii i Paleontologii. Akademiya Nauk 2: 1-40. Kiev.

Chronic, J.1949. In Upper Paleozoic of Perú (Newell, N.D.; Chronic, J; Roberts, T.G). The Geological Society of America, Bulletin 58: 1-241.

Cisterna, G.A.; Sterren, A.F. 2016. Late Carboniferous postglacial brachiopod faunas in the Southwestern Gondwana margin. Palaeoworld 25 (4): 569-580.
Cisterna, G.A.; Sterren, A.F.; López Gamundi, O.; Vergel, M.M. 2017. Carboniferous postglacial faunas in the late Serpukhovian-Bashkirian interval of central-western Argentina. Alcheringa 41 (3): 413-431.

Cohen, K.M.; Finney, S.C.; Gibbard, P.L.; Fan, J-W. 2013 (updated 2017). The ICS International Chronostratigraphic Chart. Episodes 36: 199-204.

Cucchi, R.J. 1980. La Formación Esquel: nueva interpretación estratigráfica. Revista de la Asociación Geológica Argentina 35 (2): 167-173.

Cúneo, R.; Sabattini, N. 1987. Flora y Fauna de la base de la Formación Río Genoa en la localidad Ferraroti, Pérmico inferior de Chubut, Argentina. In Congreso Latinoamericano de Paleontología; No. 4: 283-298. Bolivia.

Cuvier, G. 1795. Second mémoire sur l'organisation et les rapports des animaux à sang blanc, dans lequel on traite de la structure des Mollusques et de leur division en orders, lu à a Societé d'histoire Naturelle de Paris, le 11 Prairial, an III. Magazin Encyclopedique, ou Journal des Sciences, des Lettres et des Arts 2: 443-449.

Dall, W.H. 1889. On the hinge of pelecypods and its development, with an attempt toward a better subdivision of the group. American Journal of Science, Ser. 3, 38 (228): 445-462.

Díaz Saravia, P.; Jones, P.J. 1999. New Carboniferous (Namurian) glaciomarine ostracods from Patagonia, Argentina. Journal of Micropalaeontology 18: 97-109.

Dickins, J.M. 1963. Permian pelecypods and gastropods from western Australia. Bureau of Mineral Resources, Geology and Geophysics Bulletin 63: 1-149.

Driscoll, E.G. 1963. Paraconularia newberryi (Winchell) and other Lower Mississipian Conulariids from Michigan, Ohio, Indiana, and Iowa. Contributions from the Museum of Paleontology, University of Michigan 18: 33-46.

Du Toit, A.L. 1927. A geological comparison of South America with South Africa. Carnegie Institute Publication 381: 1-157.

Duméril, A.M.C. 1806. Zoologie analytique ou method naturelle de classification desanimaux. Allais: 334 p. Paris.

Ehrenberg, C.G. 1828-1831. Phytozoa. Symbolae physicae animalia evertebrata exclusis insectis. Series prima cum tabularum decade prima continent animalia Africana et Asiatica. In Symbolae physicae, seu Icones adhue ineditae corporum naturalium novorum aut minus cognitorum, quae ex itineribus per Libyam, Aegyptum, Nubiam, Dengalam, Syriam, Arabiam et Habessiniam. Pars Zoologica 4, Officina Academica: 65 p. Berolini. 
Engel, B.A.; Morris, L.N. 1992. Aulacopleuridae and Brachymetopidae (Trilobita) from the Lower Carboniferous of eastern Australia. (ii) Brachymetopus (Brachymetopus) and Australosutura. Geologica et Palaeontologica 26: 73-97.

Feldmann, R.M.; Babcock, L.E. 1986. Exceptionally preserved conulariids from Ohio: reinterpretation of their anatomy. National Geographic Research 2: 464-472.

Feldman, R.; Chapman, R.; Hannibal, J. 1989. Paleotechniques. The Paleontological Society Special Publication 4: $358 \mathrm{p}$.

Feruglio, E. 1941. Nota preliminar sobre la Hoja 40B, San Carlos de Bariloche. Boletín de Informaciones Petroleras 18 (200): 77-108.

Fletcher, H.O. 1938. A revision of the Australian Conulariae. Records of the Australian Museum 20: 235-255.

Flower, R.H.; Caster, K.E. 1935. The stratigraphy and paleontology of northwestern Pennsylvania, Pt. II, Paleontology; Section A: The cephalopod fauna of the Conewango Series of the Upper Devonian in New York and Pennsylvania. Bulletins of American Paleontology 22: 1-74.

Fortey, R. A. 1997. Classification. In Treatise on Invertebrate Paleontology, Part O, Arthropoda 1, Trilobita, Revised 1 (Kaesler, R.L.; editor). Geological Society of America and University of Kansas: 289-302. Boulder and Lawrence.

Fortey, R.A. 2001. Trilobite systematics: the last 75 years. Journal of Paleontology 75: 1141-1151.

Fortey, R.A.; Owens, R.M. 1975. Proetida: a new order of trilobites. Fossils and Strata 4: 227-239.

Giacosa, R.W.; Márquez, M.M. 2002. El basamento Paleozoico de la Cordillera Patagónica. In Congreso Geológico Argentino, No. 15. Geología y Recursos Naturales de Santa Cruz, Relatorio I-3: 1-11. El Calafate.

Girty, G.H. 1911. On some new genera and species of Pennsylvanian fossils from the Wewoka Formation of Oklahoma. New York Academy of Sciences Annual 21: 119-156.

Girty, G.H. 1915. Faunas of the Boone Limestone at St. Joe, Arkansas. United States Geological Survey Bulletin 598: 1-50.

González, C.R. 1969. Nuevas especies de Bivalvia del Paleozoico superior del Sistema de Tepuel, provincia de Chubut, Argentina. Ameghiniana 6 (3): 236-250.

González, C.R. 1972. La Formación Las Salinas, Paleozoico superior de Chubut (República Argentina). Parte I. Estratigrafía, facies y ambientes de sedimentación. Revista de la Asociación Geológica Argentina 27 (1): 95-115.
González, C.R. 1977. Bivalvos del Carbónico superior del Chubut, Argentina. Acta Geológica Argentina 14: 105-147.

González, C.R. 1985. El Paleozoico superior marino de la Patagonia extraandina. Ameghiniana 21 (2-4): 125-142.

González, C.R. 2010. Bivalves from the Carboniferous glacial deposits of central Patagonia, Argentina. Geologica et Palaeontologica 43: 61-81.

González, C.R.; Taboada, A.C.; Díaz Saravia, P.; Aredes, M.A. 1995. El Carbónico del sector noroccidental de la Provincia de Chubut. Revista de la Asociación Geológica Argentina 50 (14): 40-46.

González Bonorino, F. 1986. Geología de la Patagonia. Estudio regional de la Cordillera Andina, vertientes atlánticas y pacíficas, entre los paralelos $40^{\circ}$ y $52^{\circ}$ de latitud sur. Capricornio 1 (1): 1-38.

González Bonorino, F.; González Bonorino, G. 1988. La base del Grupo Tepuel en las cercanías de Esquel, Chubut. Revista de la Asociación Geológica Argentina 43(4): 518-528.

Gordon, M. 1960. Some American Midcontinent Carboniferous cephalopods. Journal of Paleontology 34: 133-151.

Gordon, M.; Yochelson, E.L. 1987. Late Mississipian Gastropods of the Chainman Shale, West central Utah. Geological Survey Professional Paper 1368: 1-107.

Götte, A. 1887. Entwicklungsgeschichte der Aurelia aurita und Cotylorhiza tuberculata. Abhandlungen zur Entwicklungsgeschichte der Tiere. Viertes Heft. Verlag von Leopold Voss: 77 p. Hamburg und Leipzig.

Gray, J.E. 1854. A revision of the arrangement of the families of bivalve shells (Conchifera). The Annals and Magazine of Natural History (series 2) 13: 408-418.

Griffis, N.P.; Montañez, I.P.; Isbell, J.; Gulbranson, E.L.; Wimpenny, J.; Yin, Q.Z.; Cúneo, N.R.; Pagani, M.A.; Taboada, A.C. 2014. U-Pb Detrital Zircon Geochronologic Constraints on Depositional Age and Sediment Source Terrains of Late Paleozoic Tepuel-Genoa Basin. American Geophysical Union. Fall Meeting abstract EP21D-3566.

Grobben, C. 1894. Zur Kenntniss der Morphologie, der Verwandtschftsverhältnisse und des Systemsder Mollusken. Sitzungsberichte der MathematischNaturwissenschaftlichen Klasse der Kaiserlichen Academie der Wissenschaften 103: 61-86.

Hahn, G.; Hahn, R. 1969. Trilobitae carbonici et permici I (Brachymetopidae; Otarionidae; Proetidae: Proetinae, Dechenellinae, Drevermanniinae, Cyrtosymbolinae). In Fossilium Catalogus I: Animalia (Westphal, F.; editor). Gravenhage, Ysel Press 118: 1-160. The Netherlands. 
Hall, J. 1858. Palaeontology of Iowa, pt. 2 of Hall, James, and Whitney, J. D., Report on the Geological Survey of the state of Iowa; embracing the results of investigations made during portions of the years 1855 , 56 and 57, 1: 473-724.

Hall, J.; Clarke, J.M. 1893. An introduction to the study of the genera of Palaeozoic Brachiopoda. Palaeontology of New York, Charles van Benthuysen and Sons: 1-317. Albany.

Hatscheck, B. 1888. Lehrbuch der Zoologie, eine morphologische Übersicht des Thierreiches zur Einfürhrung in das Stadium dieser Wissenschaft. Jena Gustav Fischer: 432 p.

Hervé, F.; Haller, M.J.; Duhart, P.; Fanning, C.M. 2005. SHRIMP U-Pb ages of detrital zircons from Cushamen and Esquel formations, North Patagonian Massif, Argentina: geological implications. In Congreso Geológico Argentino, No. 16, Actas: 309-314. La Plata.

Hervé, F.; Calderon, M.; Fanning, C.M.; Pankhurst, R.J.; Fuentes, F.; Rapela, C.W.; Correa, J.; Quezada, P.; Marambio, C. 2016. Devonian magmatism in the accretionary complex of southern Chile. Journal of the Geological Society 173 (4): 587-602.

Hill, D. 1981. Coelenterata, Rugosa and Tabulata. In Treatise on Invertebrate Paleontology, Part. F (Moore, R.C.; editor). Coelenterata 1: F5-F352. Boulder and Lawrence.

Hlebszevitsch, J.C. 2004. La Familia Acrocrinidae (Echonodermata, Crinoidea) y el límite CarboníferoPérmico en las secuencias neopaleozoicas de la Cuenca Tepuel-Genoa (Chubut, Argentina). Ameghiniana 41 (3): 381-392.

Hlebszevitsch, J.C.; Sabattini, N. 2005. Crinoids from TepuelGenoa Basin and their biostratigraphic implications. In Gondwana No. 12: Geological and Biological Heritage of Gondwana, Abstracts: p.202. Mendoza.

Hoare, R.D. 1961. Desmoinesian Brachiopoda and Mollusca from southwesten Missouri. University of Missouri Studies 6: 1-262.

Keidel, J. 1922. Sobre la distribución de los depósitos glaciares del Pérmico conocidos en la Argentina y su significación para la estratigrafía de la Serie de Gondwana y la paleogeografía del hemisferio austral. Academia Nacional de Ciencias, Boletín 25: 239-368.

Knight, J.B. 1945. Some new genera of the Bellerophontacea. Journal of Paleontology 19 (4): 333-340.

Knight, J.B. 1956. New families of Gastropoda. Journal of the Washington Academy of Sciences 46 (2): 41-42.

Koninck, L.G. 1883. Faune du calcaire Carbonifére de la Belgique. 4e partie, Gastéropodes (suite et fin). Museé
Royal d'Histoire Naturelle de Belgique, Annales 8 (4): 198-213.

Kuhn, O. 1940. Palaözoologie in Tabellen. G. Fischer: 50 p. Jena.

Kumpera, O.; Prantl, F. Růžička, B. 1960. Revision of the Nuculanidae from the Ostrava-Karviná District (Pelecypoda). Acta Musei Nationalis Pragae (serie B) Historia Naturalis 16: 17-80.

Leach, W.E. 1817. Synopsis of the orders, families and genera of the class Cephalopoda. The Zoological Miscellany; being descriptions of new or interesting animals 3: 137-141.

Lee, D.E.; MacKinnon, D.I.; Smirnova, T.N. 2007. Terebratulidina. In Treatise on Invertebrate Paleontology, Part H, Brachiopoda, Revised 6 (Selden, P.A.; editor). Geological Society of America and the Paleontological Institute of Kansas: 2801-2816. Boulder and Lawrence.

Leme, D.E.M.; Guimara, M.; Marques, A.C.; Van Iten, H. 2008. Cladistic analysis of the Suborder Conulariina Miller and Gardney, 1896 (Cnidaria, Scyphozoa; Vendian-Triassic). Palaeontology 51: 649-662.

Leme, J.M. 2006. Análise cladística de Conulariidae Walcott (Neoproterozóico-Triássico): caracterizando e definindo um grupo de cnidários extintos. $\mathrm{PhD}$. Thesis (Unpublished). Universidade de San Paulo: 107 p.

Lesta, P.; Ferello, R. 1972. Región extraandina del Chubut y norte de Santa Cruz. In Geología Regional de Argentina (Leanza, A.F.; editor). Academia Nacional de Ciencias de Córdoba: 601-654.

Linnaeus, C. 1758. Systema naturae per regna tria naturae. Regnum animale: 824 p. Edicion 10 reformada. Estocolmo.

Linares, E.; Haller, M.J.; Ostera, H.A.; Page, S.M. 2001. Preliminary radiometric ages for the Arroyo Pescado Formation. In Simposio Argentino del Paleozoico Superior, No. 2: p.16. Trelew.

López Gamundi, O. 1980. La Formación Esquel, litología y estructura. Provincia del Chubut. Revista de la Asociación Geológica Argentina 35 (2): 187-194.

Marcos, P.; Gregori, D.A.; Benedini, L.; Barros, M.; Strazzere, L.; Pavón Pivetta, C. 2017. Pennsylvanian glacimarine sedimentarion in the Cushamen Formation, western North Patagonian Massif. Geoscience Frontiers 9: 485-504.

Mariñelarena, M.P. 1970. Algunas especies de Paraconularia Sinclair del "Sistema Tepuel" (Chubut) y sus relaciones con faunas del hemisferio austral. Ameghiniana 7: 139-150.

Márquez, M.J.; Viera, R.L.M.; Ferpozzi, L.; Ubaldón, M.C.; Butrón, F.; Férnández, M.I.; Chernicoff, J.; Page, N. 
2001. Evaluación del potencial en elementos del grupo del Pt (PGE) y de minerales metalíferos asociados, en los plutones gábricos de las Sierras de Tecka y Tepuel, Chubut. Servicio Geológico Minero Argentino, Instituto de Geología y Recursos Minerales: 41 p. Buenos Aires.

Martínez Chacón, M.L.; Winkler Prins, C. 2008. New Bashkirian (Carboniferous) brachiopods from Latores (Asturias, N Spain). Proceedings of the Royal Society of Victoria 120 (1): 194-205.

Matthews, S.C. 1973. Notes on open nomenclature and on synonymy lists. Palaeontology 16: 713-719.

Maxwell, W.G.H. 1951. Upper Devonian and Middle Carboniferous Brachiopods of Queensland. University of Queensland, Department of Geology, Papers (St. Lucia) 3 (14): 1-27.

Maxwell, G.H. 1964. The geology of the Yarrol Region. Part 1. Biostratigraphy. University of Queensland Papers 5 (9): 1-60.

McCoy, F. 1844. A synopsis of the characters of the Carboniferous limestone fossils of Ireland. University Press: 207 p. Dublin.

McCoy, F. 1851. Description of some new Mountain Limestone fossils: Annals and Magazine of Natural History 7: 167-175.

McKellar, R.G. 1970. The Devonian Productoid Brachiopod Faunas of Queensland. Geological Survey of Queensland, Publications (Brisbane) 342: 1-40.

Meek, F.B. 1875. A report on some invertebrate fossils of the Waverly Group and coal measures of Ohio. In Report of the Geological Survey of Ohio (Newbury, J.S.; editor), Geology and Paleontology 2, Ohio Geological Survey: 268-347. Ohio.

Meek, F.B.; Worthen, A.H. 1866. Descriptions of invertebrates from the Carboniferous System. Illinois Geological Survey 2: 145-411.

Miller, S.A. 1889. North American Geology and Paleontology: Western Methodist Book Concern Press: 793 p. Cincinnati, Ohio.

Miller, S.A. 1891. Palaeontology. Indiana Geological Survey, $17^{\text {th }}$ Annual Report, advance sheets: 611-705.

Miller, S. A.; Gurley, W. G. E. 1896. New species of Paleozoic invertebrates from Illinois and other States. Bulletin of the Illinois State Museum of Natural History 11: 1-50.

Milne-Edwards, H.; Haime, J. 1850-1855. A monograph of the British fossil corals. Palaeontographical Society Monography, i-lxxxv 1-71, 1852, 147-210; 1853, 211 244; 1855, 245-299.

Mitchell, J. 1922. Description of two new trilobites, and note on Griffithides convexicaudatus Mitchell.
Proceedings of the Linnean Society of New South Wales 47 (4): 535-540.

Mitchell, J. 1924. New trilobites from Bowning, with notes on Encrinurus and Cordania gardneri. Proceedings of the Linnean Society of New South Wales 49 (2): 46-54.

Moore, R.C.; Jeffords, R.M. 1945. Description of lower Pennsylvanian corals from Texas and adjacent States. University of Texas Publication 4401: 77-208.

Moore, R.C.; Harrington, H. 1956. Conulata. In Treatise on Invertebrate Paleontology Part F, Coelenterata (Moore, R.C.; editor). Geological Survey of America and University of Kansas Press: F27- F38. Boulder and Lawrence.

Muir-Wood, H.M.; Cooper, G.A. 1960. Morphology, classification and life habits of the Productoidea (Brachiopoda). Memoir of the Geological Society of America 81 (i-xi): 1-447.

Newell, N.D. 1935. Some mid-Penssylvanian invertebrates from Kansas and Oklahoma: II. Stromatoporoidea, Anthozoa and Gastropoda. Journal of Paleontology 9 (4): 341-355.

Newell, N.D. 1938. Late Paleozoic pelecypods: Pectinacea. University of Kansas State Geological Survey 10: 1-123. Kansas.

Newell, N.D.; Boyd, D.W. 1995. Pectinoid bivalves of the Permian-Triassic crisis. American Museum of Natural History Bulletin 227: 1-95.

Newell, N.D.; Chronic, J.; Roberts, T.G. 1953. Upper Paleozoic of Peru. The Geological Society of America, Memoir 58: 1-241.

Ormiston, A.R. 1966. Occurrence of Australosutura (Trilobita) in the Mississippian of Oklahoma, USA. Palaeontology 9: 270-273.

Pagani, M.A. 2002. (Los bivalvos carboníferos y pérmicos de la Cuenca Tepuel-Genoa: revisión sistemática, paleobiogeografía e importancia estratigráfica. Tesis Doctoral (Inédito) de la Facultad de Ciencias Naturales y Museo de La Plata: 316 p.

Pagani, M.A. 2004. Los bivalvos carboníferos y pérmicos de Patagonia (Chubut, Argentina). Parte II: Familias Malletidae, Polidevciidae, Myalinidae e Inoceramidae. Ameghiniana 41: 271-288.

Pagani, M.A. 2005. Los bivalvos carboníferos y pérmicos de la Patagonia (Chubut, Argentina). Parte III: Familias Mytilidae, Pterineidae, Limidae, Leptochondriidae, Etheripectinidae, Euchondriidae y Streblochondriidae. Ameghiniana 42: 579-596.

Pagani, M.A. 2006. Los bivalvos carboníferos y pérmicos de la Patagonia (Chubut, Argentina). Parte 
IV: Familias Aviculopectinidae, Deltopectinidae y Schizodidae. Ameghiniana 43: 461-476.

Pagani, M.A.; Taboada, A.C. 2010. The marine upper Palaeozoic in Patagonia (Tepuel-Genoa Basin, Chubut Province, Argentina): 85 years of work and future prospects. Palaeogeography, Palaeoclimatology, Palaeoecology 298: 130-151.

Pagani, M.A.; Taboada, A.C. 2011. The Cisuralian faunal succession in Patagonia (Tepuel-Genoa Basin, Argentina): an updated brachiopod biostratigraphic scheme. Memoirs of the Association of Australasian Palaeontologists 41: 339-350.

Page, R.; Limarino, C.O.; López Gamundi, O.R.; Page, S. 1984. Estratigrafía del Grupo Tepuel en su perfil tipo y en la región de El Molle, provincia del Chubut. In Congreso Geológico Argentino, No 9, Acta 1: 619-632. San Carlos de Bariloche.

Pankhurst, R.J.; Rapela, C.W.; Tassone, A. 2006. Gondwanide continental the origin of Patagonia. Earth-Science Reviews 76: 235-257.

Pemberton, M. 2010. Las plantas fósiles de la Sierra de Tepuel, Paleozoico Superior de la provincia del Chubut. Seminario de Licenciatura en Ciencias Biológicas (Unpublished). Facultad de Ciencias Naturales, Universidad Nacional de la Patagonia San Juan Bosco: 96 p.

Peou, S.; Engel, B.A. 1979. A Carboniferous Fauna from Rawdon Vale, New South Wales. Alcheringa 3 (2): 141-157.

Perrot, C.J. 1960. Estudio geológico de las inmediaciones del paraje "El Molle" departamento Tehuelches, prov. de Chubut. Revista de la Asociación Geológica Argentina 15 (1-2): 53-79.

Petersen, K. 1979. Development of coloniality in Hydrozoa. In Biology and Systematics of colonial organisms (Larwood and Rosen; editors). Systematics Association Special Volume 11. Academic Association Press: 105-139. London.

Piatnitzky, A. 1933. Rético y Liásico de los valles de los ríos Genoa y Tecka y sedimentos continentales de la sierra de San Bernardo. Boletín de Informaciones Petroleras 10: 151-182.

Piatnitzky, A. 1936. Estudio geológico de la región del Río Chubut y del Río Genoa. Boletín de Informaciones Petroleras 13: 83-118.

Pinilla, M.K. 2012. The new species Ananias riccardii (Gastropoda, Eotomariidae) from the Cisuralian of Patagonia, Argentina. Revue de Paléobiologie 11: 357-364.

Pinilla, M.K. 2014. Gastrópodos del Paleozoico Superior de la Cuenca de Tepuel-Genoa, Provincia del Chubut,
Argentina. Ph.D. Thesis (Unpublished), Universidad Nacional de La Plata: 214 p. La Plata.

Polanski, J. 1978. Carbónico y Pérmico de la Argentina. Eudeba Manuales, Editorial Universitaria de Buenos Aires: 216 p. Buenos Aires.

Prantl, F.; Prribyl, A. 1950. A revision of the Bohemian representatives of the family Otarionidae R. and E. Richter(Trilobitae). Sborník státníhogeologické hoústavu československé republiky, oddíl paleontologický 17: 353-512.

Ramos, V.A. 1984. Patagonia, un continente paleozoico a la deriva? In IX Congreso Geológico Argentino, Actas 2: 311-325. San Carlos de Bariloche.

Ramos, V.A. 2008. Patagonia: a Paleozoic continent drift? Journal of South American Earth Sciences 26 (3): 235-251.

Reed, F.R.C. 1927. Upper Carboniferous Fossils from Argentina. In Geological Comparison of South America with South Africa (Du Toit, A.L.; editor). Carnegie Institution of Washington Publications 381: 129-150. Washington.

Revol, P. 1988. Geología de un sector del norte de la Sierra de Tecka, borde occidental, Departamento de Languiñeo, Provincia del Chubut. Trabajo Final de Licenciatura (Unpublished), Universidad de Buenos Aires: 95 p. Buenos Aires.

Riccardi, A.; Sabattini, N. 1975. Cephalopoda from the Carboniferous of Argentina. Palaeontology 18 (1): 117-136.

Rich, M. 1966. Mississippian trilobites from northwestern Georgia. Journal of Paleontology 40: 1381-1384.

Robbiano, J.A. 1971. Contribución al conocimiento estratigráfico de la sierra del Cerro Negro, Pampa de Agnia, provincia de Chubut, Argentina. Revista de la Asociación Geológica Argentina 26: 41-52.

Roberts, J.; Hunt, J.W.; Thompson, D.M. 1976. Late Carboniferous Marine Invertebrate Zones of Eastern Australia. Alcheringa 1 (2): 197-225.

Rocha-Campos, A.C. 1966. Novas ocorréncias de fósseis marinos no Grupo Tubarăo em SănPaulo e Santa Catarina. Boletim da Sociedade Brasileira de Geología 15 (4): 5-13.

Rolleri, E.O. 1970. Discordancia en la base del Neopaleozoico al este de Esquel. In Jornadas Geológicas Argentinas, No. 4, Actas 4: 273-319. Mendoza.

Rowley, R.R. 1908. The Geology of Pike County. Missouri Bureau of Geology and Mines, Second Series 8: 1-122.

Sabattini, N. 1972. Los Fenestellidae, Acanthocladiidae y Rabdomesidae (Bryozoa, Cryptostomata) del Paleozoico superior de San Juan y Chubut, Argentina. Revista 
del Museo de La Plata (nueva serie) Paleontología 6 (42): 255-377.

Sabattini, N. 1978. Gastrópodos Carbónicos y Pérmicos del Grupo Tepuel (provincia de Chubut, Argentina). Obra del Centenario del Museo de La Plata 5: 39-62.

Sabattini, N. 1980. Gastrópodos marinos Carbónicos y Pérmicos de la Sierra de Barreal (Provincia de San Juan). Ameghiniana 18 (2): 109-119.

Sabattini, N. 1986. Distribución Geográfica y Estratigráfica de los Cnidaria y Bryozoa del Carbonífero y Pérmico de la Argentina. Revista del Museo de La Plata (N.S): 9, Paleontología 51: 1-17.

Sabattini, N. 2002. Cystoporata (Bryozoa) del Carbonífero de la cuenca Tepuel-Genoa, Provincia de Chubut, Argentina. Ameghiniana 39 (2): 201-211.

Sabattini, N.; Noirat, S. 1969. Algunos gastrópoda de las Superfamilias Euomphalacea, Pleurotomariacea y Platyceratacea del Paleozoico superior de Argentina. Ameghiniana 6 (2): 98-117.

Sabattini, N.; Hlebszevitsch, J.C. 2004. Agrupamientos radiales de conuláridos del Pérmico inferior de la Provincia de Chubut, Argentina. Ameghiniana 41(3): 399-404.

Sarytcheva, T.G. 1960. Brachiopoda. In Osnovy Paleontologii (Orlov, Y.A.; editor). Akademiia Nauk SSSR 7: 115304. Moscow.

Sarytcheva, T.G. 1968. Brakhiopody verkhnego paleozoia vostochnogo Kazakhstana. (Late Paleozoic Brachiopods of Western Kazakhstan.). Akademiia Nauk SSSR, Paleontologicheskii Institut, Trudy 121: 1-212.

Sarytcheva, T.G.; Sokolskaja, A.N. 1959. O klassifikatsin lozhnoporistykh brakhiopod. (On the Classification of Pseudopunctate Brachiopods.). Akademiia Nauk SSSR, Doklady 125 (1): 181-184.

Schuchert, Ch. 1913. Class 2. Brachiopoda. In Text-book of Palaeontology 1, part 1 (von Zittel, K.A; editor). MacMillan: 355-420. London.

Sendino, M.C. 2007. Revisión de la colección de Conulariidae de the Natural History Museum of London (Reino Unido). PhD. Thesis (Unpublsished). Universidad Complutense de Madrid: 98 p.

Shevyrev, A.A. 2006. The Cephalopod Macrosystem: A Historical Review, the Present State of Knowledge, and Unsolved Problems: 2. Classification of Nautiloid Cephalopods. Paleontological Journal 40 (1): 46-54.

Simanauskas, T. 1996. Braquiópodos (Productoidea) del Pérmico de la cuenca Tepuel-Genoa, Chubut, Argentina. Ameghiniana 33 (4): 377-383.

Simanauskas, T.; Sabattini, N. 1997.Bioestratigrafía del Paleozoico Superior marino de la Cuenca Tepuel-
Genoa, Provincia del Chubut, Argentina. Ameghiniana 34: 49-60.

Simanauskas, T.; Cisterna, G. 2001. Braquiópodos articulados de la Formación El Paso, Paleozoico superior, Precordillera Argentina. Revista Española de Paleontología 16 (2): 209-222.

Simões, M.G.; Rodrigues, S.C.; Leme, J.D.M. 2003. Some middle paleozoic conulariids (Cnidaria) as possible examples of taphonomic artifacts. Journal of Taphonomy 1: 165-186.

Sinclair, W.G. 1940. The genotype of Conularia. Canadian Field Naturalist 54 (5): 72- 74.

Sinclair, W.G. 1952. A classification of the Conularida. Chicago Natural History Museum 10: 135-145.

Sloan, R.E. 1955. The Carboniferous Genus Glabrocingulum Thomas. Fieldiana 10 (22): 275-281.

Smirnova, T.N. 2004. The lower Kazanian (upper Permian) terebratulid assemblage of the family Beecheridae fam. nov. (Brachiopoda) from the east of the Russian Platform. Paleontologicheskii Zhurnal 38 (2): 166-171.

Spikerman, J.P. 1978. Geología de los alrededores de la estancia Arroyo Pescado, Chubut. Revista de la Asociación Geológica Argentina 32 (4): 265-276.

Stehli, F.G. 1954. Lower Leonardian Brachiopoda of the Sierra Diablo. American Museum of Natural History, Bulletin 105 (3): 257-358.

Suero, T. 1948. Descubrimiento del Paleozoico superior en la zona extraandina del Chubut. Boletín de Informaciones Petroleras 25 (287): 1-20.

Suero, T. 1953. Las sucesiones sedimentarias suprapaleozoicas de la zona extraandina del Chubut. Revista de la Asociación Geológica Argentina 8: 39-59.

Suero, T. 1958. Datos geológicos sobre el Paleozoico superior en la zona de Nueva Lubecka y alrededores (Chubut extra-andino, provincia Chubut). Revista del Museo de La Plata (nueva serie), Sección Geología 5: 1-28.

Suero, T. 1961. Paleogeografía del Paleozoico superior en la Patagonia (República Argentina). Revista de la Asociación Geológica Argentina 16: 35-42.

Swart, R.H. 1998. Revision of Permian Pleurotomarian gastropods from the Carnarvon and Bonaparte Basins, Western Australia. Proceedings of the Royal Society of Victoria 110 (1-2): 163-172.

Sweet, W. 1964. Nautiloidea, Orthocerida. In Treatise on Invertebrate Paleontology, Part K, Mollusca 3 (Moore, R.C.; editor). Geological Society of America and University of Kansas: 216-261. Boulder and Lawrence.

Taboada, A.C. 1989. La fauna de la Formación El Paso, Carbonífero inferior de la Precordillera sanjuanina. Acta Geológica Lilloana 17 (1): 113-129. 
Taboada, A.C. 1997. Bioestratigrafía del Paleozoico superior marino del Valle de Calingasta-Uspallata, provincias de San Juan y Mendoza. Ameghiniana 34 (2): 215-246.

Taboada, A.C. 2001. Bioestratigrafía del Neopaleozoico del Valle de Tres Lagunas, Sierra de Tepuel, provincia de Chubut. Acta Geológica Lilloana 18 (2): 291-304.

Taboada, A.C. 2006. Tivertonia Archbold (Chonetidina, Brachiopoda) del Pérmico Inferior de la subcuenca Calingasta-Uspallata, Precordillera argentina. Ameghiniana 43 (4): 705-716.

Taboada, A.C. 2008. First record of the Late Paleozoic brachiopod Verchojania in Patagonia, Argentina. Proceedings of the Royal Society of Victoria 120 (1): 305-319.

Taboada, A.C. 2010. Mississippian-Early Permian brachiopods from western Argentina: Tools for middleto high-latitude correlation, paleobiogeographic and paleoclimatic reconstruction. Palaeogeography, Palaeoclimatology, Palaeoecology 298: 152-173.

Taboada, A.C.; Pagani, M.A. 2010. The coupled occurrence of Cimmeriella-Jakutoproductus (Brachiopoda: Productidina) in Patagonia: implications for Early Permian high to middle paleolatitudinal correlations and paleoclimatic reconstruction. Geologica Acta 8: 513-534.

Taboada, A.C.; Shi, G.R. 2011. Taxonomic review and evolutionary trends of Levipustulini and Absenticostini (Brachiopoda) from Argentina: palaeobiogeographic and palaeoclimatic implications. Memoirs of the Association of Australasian Paleontologists 41: 87-114.

Taboada, A.C.; Archbold, N.W.; González, C.R.; Sabattini, N. 2005. The Late Carboniferous-Early Permian Tepuel fauna of Patagonia: updated brachiopods records. In Gondwana, No. 12, Geological and Biological Heritage of Gondwana, Abstracts: p. 349. Mendoza.

Taboada, A.C.; Pagani, M.A.; Puerta, P. 2009. An approach to the Carboniferous-Early Permian stratigraphy, paleontology, paleogeography and paleoclimatology of the Calingasta-Uspallata Subbasin (western Argentina) and Tepuel-Genoa Basin (Patagonia), Argentina: a fieldguide. Permophiles 53: 11-48.

Taboada, A.C.; Mory, A.C.; Shi, G.R.; Haig, D.W.; Pinilla, M.K. 2015. An Early Permian brachiopod-gastropod fauna from the Calytrix Formation, Barbwire Terrace, Canning Basin, Western Australia. Alcheringa 39: 207-223.

Taboada, A.C.; Taboada, C.A.; Pardo, C.A.; Césari, S. 2018. Formación Valle Chico, Esquel, Chubut: Actualización del registro paleontológico, discusión estratigráfica e implicancias paleoclimáticas. In Simposio Argentino del Paleozoico Superior, No. 7, Revista del Museo de La Plata, Suplemento Resúmenes 20R-21R. Esquel.

Thomas, E.G. 1940. Revison of the Scottish Carboniferous Pleurotomariidae. Geological Society of Glasgow 20 (2): 30-72.

Turner, J.C.M. 1982. Descripción geológica de la Hoja 44C Tecka (Provincia del Chubut). Boletín Facultad de Ciencias Exactas y Naturales de la Universidad de Buenos Aires y Servicio Geológico Nacional 197: 1-92.

Van-Iten, H.; Simoes, M.G.; Marques, A.C.; Collins, A.; Leme, D.E.M. 2006. Cladistic analysis of the Suborder Conulariina Miller and Gardney, 1896 (Cnidaria, Scyphozoa; Vendian-Triassic). Journal of Systematic Palaeontology 4: 109-118.

Verrill, A.E. 1865. Classification of polyps (Extract condensed from a synopsis of the polypi of the North Pacific exploring Expedition, under captains Ringgold and Rodgers, U.S.N.). Essex Institution, Proceedings 4: 145-149.

Vizán, H.; Alberti, R.; Revol, P.; Conti, E.; Spikerman, J.P. 1996. Geología del extremo septentrional de la sierra de Tecka (Chubut). Nueva interpretación para la estratigrafía del área de Ap Iwan. Revista de la Asociación Geológica Argentina 51 (4): 365-377.

Von Salvini-Plawen, L. 1980. A reconsideration of systematics in the Mollusca (Phyllogeny and higher classification). Malacologia 19 (2): 249-278.

Waagen, W. 1883. Salt Range Fossils. I. ProductusLimestone Fossils. Geological Survey of India, Memoirs, Palaeontologia Indica (series 13), 4 (2): 391-546.

Walch, J.E.I. 1771. Die Naturgeschichte der Versteinerungen zur Erläuterung der Knorrischen Sammlung von Merkwürkigkeiten der Natur 4 (3): 235 p. Nürnberg.

Walcott, C.D. 1886. Cambrian faunas of North America. Oklahoma City, United States Geological Survey 30: 72-89.

Waterhouse, J.B. 1971. Systematic Description of New Brachiopod Species and Genera. In Carboniferous and Permian Stratigraphy and Paleontology, Northern Yukon Territory, Canada (Bamber, E.W.; Waterhouse, J.B.; editors). Canadian Petroleoum Geology, Bulletin 19: 205-250.

Waterhouse, J.B. 1982. New Carboniferous Brachiopod Genera from Huai Bun Nak, North-East Thailand. Palaeontologische Zeitschrift 56 (1-2): 39-52.

Waterhouse, J.B. 2001. Late Paleozoic Brachiopoda and Mollusca from Wairaki Downs, New Zealand. With 
notes on Scyphozoa and Triassic ammonoids and new classifications of Linoproductoidea (Brachiopoda) and Pectinida (Bivalvia). Earthwise 3: 1-195.

Waterhouse, J.B. 2008, Aspects of the evolutionary records for fossils of the bivalve subclass Pteriomorphia Beurlen. Earthwise 8: 1-220.

Waterhouse, J.B. 2013. The evolution and classification of Productida (Brachiopoda). Earthwise 10: 1535.
Wenz, W. 1938. Gastropoda. In Handbuch der Paläozoologie (Schindewolf, O.H.; editor): 6 (1): 1-240. Berlin. Williams, J.S. 1943. Stratigraphy and fauna of the Louisiana Limestone of Missouri. Geological Survey Professional Paper 203: 1-131.

Yuan, J.; Xiang, L. 1998. Trilobite fauna at the DevonianCarboniferous boundary in South China (S-Guizhou and N-Guangxi). National Museum of Natural Science, Special Publication 8: 1-281.

Manuscript received: December 30, 2017; revised/accepted: November 6, 2018; available online: February 4, 2019. 